J. Dairy Sci. 95:6695-6715

http://dx.doi.org/10.3168/jds.2012-5685

(C) American Dairy Science Association ${ }^{\circledR}, 2012$.

\title{
Metabolic characteristics of proteins and biomolecular spectroscopic profiles in different batches of feedstock (wheat) and their co-products (wheat distillers dried grains with solubles) from the same bioethanol processing plant
}

\author{
Inoka H. Gamage, Arjan Jonker, David A. Christensen, and Peiqiang $\mathrm{Yu}^{1}$ \\ College of Agriculture and Bioresources, University of Saskatchewan, 51 Campus Drive, Saskatoon, SK, Canada, S7N 5A8
}

\begin{abstract}
The objectives of this study were (1) to reveal the metabolic characteristics of proteins in different batches of feedstock (wheat) for bioethanol production and their co-products (wheat distillers dried grains with solubles, wDDGS) from the same bioethanol processing plant, and (2) to characterize biomolecular spectral profile associated with nutrient digestion in the rumen and intestine of dairy cattle. The metabolic characteristics of proteins were determined using the DVE/OEB system (where DVE = total truly absorbed protein supply, and OEB = degraded balance of protein) based on chemical profiles and rumen and intestinal digestion data from dairy cattle. The biomolecular spectral characteristics were investigated by using the molecular spectroscopy technique attenuated total reflectanceFourier transform infrared spectroscopy (ATR-FT/IR). Multivariate molecular spectral analyses - agglomerative hierarchical cluster analysis (AHCA), and principal component analysis (PCA) - were conducted to identify the spectral differences in biomolecular inherent structure among the wheat and wDDGS batches. The results showed that (1) the metabolic characteristics of proteins in the wheat and wDDGS from the same bioethanol processing plant were significantly affected by batch, with total truly absorbed protein supply (DVE value) ranging from 101 to $116 \mathrm{~g} / \mathrm{kg}$ of dry matter (DM) in wheat and from 153 to $182 \mathrm{~g} / \mathrm{kg}$ of DM in wDDGS; (2) the degraded balance of protein (OEB value) in the wDDGS (but not the wheat) from the same bioethanol processing plant was significantly affected by batch, with the OEB value ranging from -19 to $-26 \mathrm{~g} / \mathrm{kg}$ of $\mathrm{DM}$ in the wheat and from 145 to $181 \mathrm{~g} / \mathrm{kg}$ of DM in the wDDGS; and (3) the biomolecular spectral analyses with AHCA and PCA revealed biomolecular spectral
\end{abstract}

Received May 2, 2012.

Accepted June 25, 2012.

${ }^{1}$ Corresponding author: peiqiang.yu@usask.ca profiles and differences among the wheat and wDDGS samples.

Key words: bioethanol feedstock and co-products, metabolic characteristics of proteins, biomolecular spectral profile

\section{INTRODUCTION}

With expansion of the biofuel industry in North America, the availability of co-products from bioethanol processing (distillers dried grains with solubles) to the market also increased (CRFA, 2010). A major concern is how to maintain consistency of co-product quality (Nuez-Ortín and Yu, 2009, 2010). Published studies have focused on co-product quality pertaining to physical characteristics, nutrient composition, and nutrient availability to the animal, especially among co-products from different bioethanol plants of origin (Shurson et al., 2001; Stein et al., 2006; Belyea et al., 2010). Recent studies have shown that molecular spectroscopy techniques such as synchrotron-radiation based infrared microspectroscopy (SR-IMS; Yu, 2006), diffuse reflectance infrared Fourier transform (DRIFT) molecular spectroscopy (Doiron et al., 2009a,b; Yu et al., 2011), and attenuated total reflectance-Fourier transform infrared (ATR-FT/IR) molecular spectroscopy (Jonker et al., 2011) could be used to reveal processing-induced or treatment-induced changes in intrinsic biomolecular structures and to detect the chemical structure differences among the treatments such as heat processing and gene transformation (Yu, 2010).

To our knowledge, studies are lacking on the metabolic characteristics of protein among feedstock batches for bioethanol production and their co-products from the same wheat-based bioethanol processing plant. Differences of inherent molecular structures among feedstock batches for bioethanol production and their co-products from the same bioethanol processing plant have not been studied. No evaluation has been done on the sensitivity of molecular spectroscopy techniques to detect differences in chemical structure on the molecular level between different batches of feedstock and 
their co-products. Large variation between batches may result in large biological differences in animal performance when co-products are fed at a high level in diet rations.

The objectives of this study were (1) to reveal the metabolic characteristics of proteins of wheat for bioethanol production and the proteins of their co-products (wheat distillers dried grains with solubles, wDDGS) from the same bioethanol processing plant, and (2) to characterize the biomolecular spectral profile associated with nutrient digestion in the rumen and intestine in dairy cattle among the batches of wheat and wDDGS. The hypothesis of this study was that differences in the metabolic characteristics of proteins among wheat and wDDGS from the same bioethanol processing plant were significant. The response and sensitivity of biomolecular structure to bioethanol processing were different among the wheat batches and their co-products. These differences could be detected by the molecular spectroscopy techniques with multivariate molecular spectral analyses [agglomerative hierarchical cluster analysis (AHCA) and principal component analysis (PCA); $\mathrm{Yu}, 2005]$. The differences were associated with the metabolic characteristics of proteins and nutrient digestion in the rumen and intestine of dairy cattle.

\section{MATERIALS AND METHODS}

\section{Bioethanol Feedstock Batches and Co-Products from Bioethanol Processing}

All samples were obtained from the same newly built bioethanol plant with current bioethanol processing technology in western Canada. Thirty samples were collected from 5 batches $(1,2,3,4,5)$ of feedstock grain (wheat: 3 samples per batch) for bioethanol processing and 5 batches (I, II, III, IV, V) of corresponding coproducts (wDDGS: 3 samples per batch). The collection was carried out over $1 \mathrm{yr}$.

\section{Molecular Spectroscopic Study}

The analyses of the feedstock and their co-products by molecular vibrational spectroscopy ATR-FT/IR were carried out at the University of Saskatchewan using a Jasco FT/IR-4200 spectroscope with a ceramic infrared light source and a deuterated L-alanine doped triglycine sulfate detector (Jasco Corp., Tokyo, Japan), comprising a MIRacle ATR accessory module and equipped with a ZnSe crystal and pressure clamp (Pike Technologies, Madison, WI). The samples were ground through a $0.25-\mathrm{mm}$ screen twice (Retsch ZM-1, Brinkmann Instruments Ltd., Mississauga, ON, Canada).
The spectra were generated from the mid-IR $(4,000-800$ $\mathrm{cm}^{-1}$ ) portion of the electromagnetic spectrum with 256 co-added scans and a spectral resolution of $4 \mathrm{~cm}^{-1}$. The spectra were generated with Jasco SpectraManager II software. Each sample was analyzed 5 times. Figure 1 shows typical ATR-FT/IR molecular spectra of the feedstock (wheat) and co-product (wDDGS) from bioethanol production in the whole mid-IR region $\left(\sim 4,000-800 \mathrm{~cm}^{-1}\right)$ and fingerprint region $(\sim 1,800-800$ $\left.\mathrm{cm}^{-1}\right)$.

The spectra were analyzed with Omnic 7.2 software (Spectra Tech, Madison, WI), and the identification of specific bands in the spectrum was done by comparison with published reference spectrum data (Jackson and Mantsch, 1995, 2000, 2002; Wetzel et al., 1998; Stuart, 2004; Marinkovic and Chance, 2005), as described in detail by $\mathrm{Yu}(2004)$.

\section{Chemical Analysis}

Samples of wheat and wDDGS were ground through a 1-mm screen (Retsch ZM-1, Brinkmann Instruments Ltd.). For analysis of starch, the samples were ground through a $0.5-\mathrm{mm}$ screen with the same Retsch ZM-1 grinder. Samples were analyzed for DM (method 930.15), ash (method 942.05), CP (method 984.13), and crude fat (CFat, method 954.02) according to the procedures of AOAC (1990). The starch was analyzed with Megazyme Total Starch Assay Kit (Megazyme International Ireland, Bray, Co. Wicklow, Ireland) according to the $\alpha$-amylase/amyloglucosidase method (McCleary et al., 1997). Neutral detergent fiber and ADF (Ankom A200 Filter Bag Technique, Ankom Technology, Fairport, NY) were analyzed (Van Soest et al., 1991). The acid (ADICP) and neutral (NDICP) detergent insoluble $\mathrm{CP}$ were determined according to Licitra et al. (1996). Nitrogen-adjusted NDF (NDFn) was calculated as NDF - NDICP. Nonprotein nitrogen was analyzed by precipitating true protein with tungstic acid and calculated as the difference between total $\mathrm{N}$ and $\mathrm{N}$ content of the residue after filtration. Total soluble CP (SCP) was determined by incubating sample with bicarbonate phosphate buffer and filtering through Whatman \#54 filter paper (Roe et al., 1990). Nonstructural carbohydrates, which may include starch, sugars, organic acids, and other reserve carbohydrates such as fructans were calculated as NFC (NRC, 2001). Ethanol-soluble carbohydrate (ESC) was analyzed according to Hall et al. (1997). Macro- and micromineral analyses (AOAC, 2000; method 985.01) were carried out in Central Testing Laboratory Ltd. (Nisku, AB, Canada) and Saskatchewan Research Council (Saskatoon, SK, Canada). 
a)

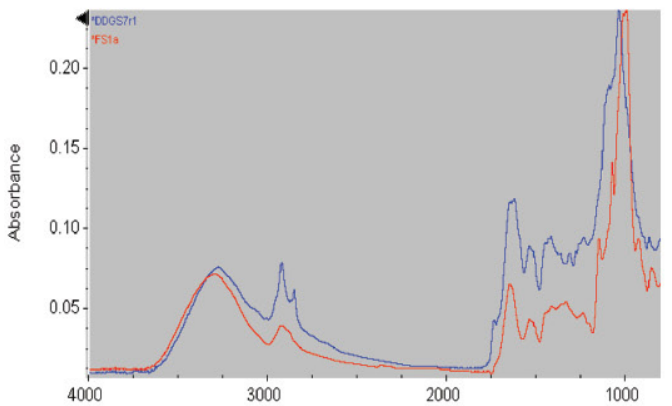

b)

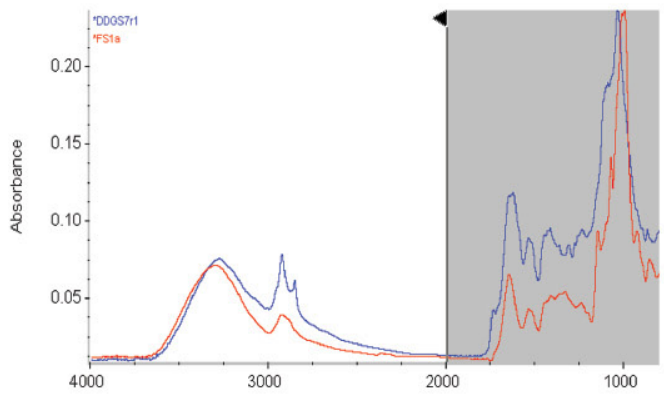

c)

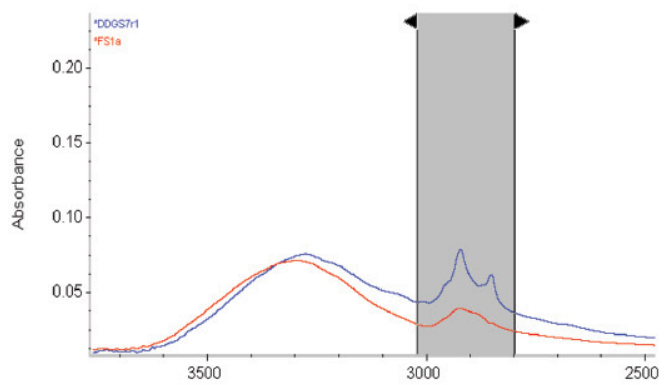

d)

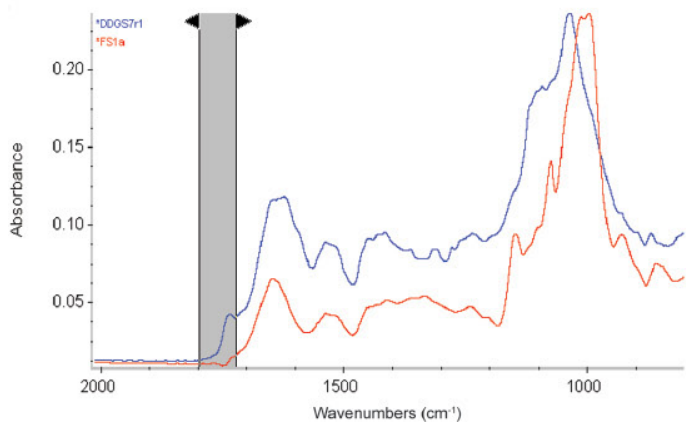

e)

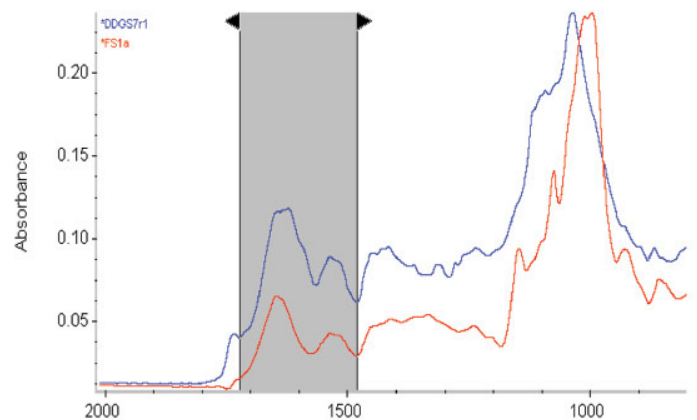

f)

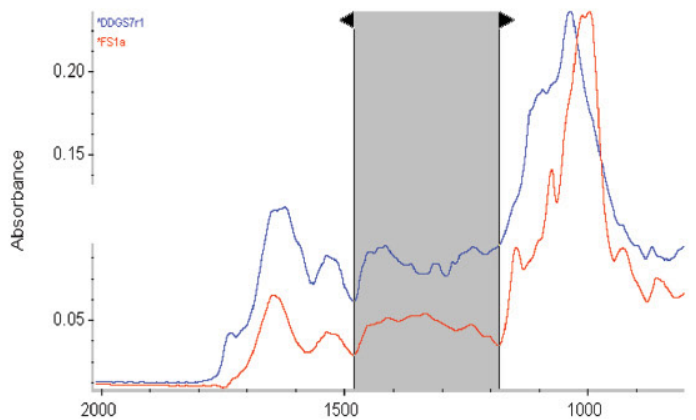

g)

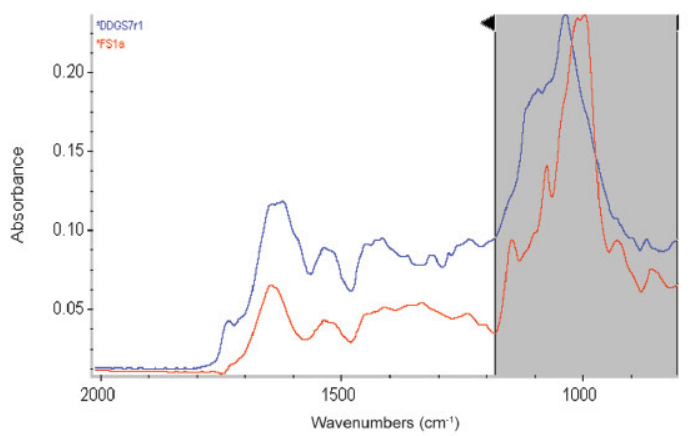

Figure 1. Fourier transform (FT) infrared (IR) attenuated total reflectance (ATR) biomolecular spectrum of feedstock (wheat) for bioethanol production (bottom, red) and co-products from bioethanol processing (wheat distillers dried grains with solubles, wDDGS; top, blue) in different windows (shaded) used for multivariate molecular spectral analyses (principal component analysis and hierarchical cluster analysis). (a) Window 1: whole mid-IR region: $\sim 4,000-800 \mathrm{~cm}^{-1}$; (b) window 2: fingerprint region: $\sim 1,800-800 \mathrm{~cm}^{-1}$ (various biomolecular functional groups in this region); (c) window 3: $\mathrm{CH}_{2}$ and $\mathrm{CH}_{3}$ asymmetric and symmetric stretching region: $\sim 3,022-2,800 \mathrm{~cm}^{-1}$ (mainly related to lipid biomolecular structure conformation); (d) window 4: carbonyl $\mathrm{C}=\mathrm{O}$ ester region: $\sim 1,800-1,725 \mathrm{~cm}^{-1}$ (mainly related to lipid biomolecular structure conformation); (e) window 5: amide I and amide II region: $\sim 1,725-1,482 \mathrm{~cm}^{-1}$ (mainly related to protein biomolecular structure conformation); (f) window 6: structural carbohydrate (CHO) region: $\sim 1,482-1,180 \mathrm{~cm}^{-1}$ (mainly related to $\mathrm{CHO}$ structural conformation); (g) window 7: $\mathrm{CHO}$ region: $1,180-800 \mathrm{~cm}^{-1}$ (mainly related to CHO structural conformation). Color version available in the online PDF. 


\section{Partitioning Protein and Carbohydrate Subfractions}

The Cornell Net Carbohydrate and Protein System (CNCPS; Sniffen et al., 1992; Chalupa and Sniffen, 1994) was applied to partition the protein and carbohydrates of the feedstock of wheat and wDDGS. Protein is fractioned into an immediately available NPN (PA), true potentially degradable protein $(\mathbf{P B})$, and undegradable protein ADICP (PC). Fraction PC is associated with lignin, tannin-protein complexes, and Maillard products, and it is completely unavailable for the animal (Cromwell et al., 1993). Fraction PB was further subdivided into 3 subfractions depending on inherent degradation rates in rumen. The rapidly degradable fraction (PB1) is buffer soluble protein that is precipitated by tungstic acid, the intermediately degradable fraction (PB2) is protein insoluble in buffer but soluble in neutral detergent and is slowly degradable and the slowly degradable fraction (PB3) is protein that is insoluble in neutral detergent but soluble in acid detergent. Most of the PB3 fraction escapes rumen fermentation to small intestine. The fraction PB3 is the protein associated with the cell wall (Krishnamoorthy et al., 1982; Van Soest et al., 1991).

In the CNCPS system (Sniffen et al., 1992), carbohydrates (CHO) are categorized into 4 subfractions according to rumen degradation rates. Rapidly degradable $\mathrm{CHO}$ fraction A (CA) consists of water-soluble sugars. Intermediately degradable fraction B1 (CB1) consists of starch and soluble fiber. Slowly degradable fraction B2 (CB2) consists of available cell walls. Fraction $\mathrm{C}(\mathbf{C C})$ consists of completely unavailable cell walls. The fraction CA and CB1 belongs to the nonstructural CHO (Sniffen et al., 1992).

\section{Digestible Nutrients and Energy Values}

Truly digestible CP (tdCP), FA (tdFA), NDF (tdNDF), and NFC (tdNFC) and TDN $\left(\mathbf{T D N}_{\mathbf{1 \times}}\right.$, TDN at maintenance) were determined using the NRC (2001) summary approach (Weiss et al., 1992). Both $\mathrm{NE}_{\mathrm{M}}$ and $\mathrm{NE}_{\mathrm{G}}$ were determined using the $\mathrm{NRC}$ (1996) beef model. Digestible energy $\left(\mathbf{D E}_{3 \times}, \mathbf{D E}_{4 \times}\right)$, $\operatorname{ME}\left(\mathbf{M E}_{3 \times}, \mathbf{M E}_{4 \times}\right)$, and $\mathrm{NE}_{\mathrm{L}}\left(\mathbf{N E L}_{3 \times}, \mathbf{N E L}_{4 \times}\right)$ at a production level of intake (3 or 4 times maintenance intake, respectively) were determined using the NRC dairy model (Weiss et al., 1992; NRC, 2001).

\section{Particle Size Distribution}

For the particle size analysis, the feedstock samples of wheat were coarsely rolled with a roller gap of 0.203 mm (Sven Grain Mill, Apollo Machine and Products
Ltd., Saskatoon, SK, Canada), and the wDDGS samples were used as is (because they were mash samples). The particle size analysis was carried out with Tyler RoTap (Mentor, $\mathrm{OH}$ ), which consists of a simultaneous sieving and tapping system. The 6 standard USA sieve numbers were used and the pan numbers were \#6, 8, $12,16,20,30$, and the bottom pan, with sieve diameter openings of $3.36,2.38,1.68,1.19,0.84$, and $0.59 \mathrm{~mm}$, respectively. Particles $<0.59 \mathrm{~mm}$ accumulate in the bottom pan. Approximately $100 \mathrm{~g}$ of sample was used at each time of sieving, and 3 replicate sievings were carried out for each sample. The sieve stack was arranged such that the coarsest particles were in the top and finest particles were in the bottom. The weighed sample was placed in the top pan. The shaker was run for $10 \mathrm{~min}$ for each sieving and the sample that remained in each sieve was weighed separately. After each sieving, the stack of sieves was thoroughly cleaned. The averaged particle size of the sample retained on a sieve was calculated using the method published by Pfost and Headley (1976).

\section{In Situ Rumen Incubation}

Four nonlactating Holstein-Friesian cows each fitted with a rumen cannula with an internal diameter of 10 $\mathrm{cm}$ were used for the in situ rumen incubation. The cows were individually fed at 0800 and $1600 \mathrm{~h}$ twice daily at maintenance level, in accordance with NRC (2001) nutrient requirements. The animals were cared for according to the guidelines of the Canadian Council on Animal Care (CCAC, 1993). Rumen degradation characteristics of nutrients were measured using the method described by $\mathrm{Yu}$ et al. (2000). Approximately $7 \mathrm{~g}$ of sample was weighed into each $10-\times 20-\mathrm{cm}$ numbered nylon bag (Nitex 03-41/31 monofilament open mesh fabric, Screentec Corp., Mississauga, ON, Canada) with a pore size of $40 \mu \mathrm{m}$. Before incubation, the feedstock samples of wheat were coarsely rolled through 0.203-mm roller gap (Sven Grain Mill) in the College of Engineering at the University of Saskatchewan. The study was conducted in 2 experimental runs and, in each run, the treatments were randomly assigned among the 4 cows. The incubation time points were 0 , $2,4,8,12,24,48$, and $72 \mathrm{~h}$. The "gradual addition/ all out" method was followed. The 0 -h samples were treated in the laboratory according to the procedure of Azarfar et al. (2007) to determine the soluble and insoluble washable fractions. After incubation, bags were removed from rumen and washed 5 times in a bucket with cold tap water to remove excess ruminal contents. Subsequently, bags were dried at $55^{\circ} \mathrm{C}$ for $48 \mathrm{~h}$. Dried samples were stored in a refrigerated cool room $\left(4^{\circ} \mathrm{C}\right)$ until analysis. 


\section{Rumen Degradation Kinetics of Various Nutrients}

Rumen degradation characteristics of nutrients were determined for DM, OM, CP, NDF, and NFC using the DVE/OEB system (Tamminga et al., 1994, 2007), where DVE = total truly absorbed protein supply, and OEB $=$ degraded balance of protein. The in situ data were fitted in the modified first-order kinetic equation (Ørskov and McDonald, 1979; Robinson et al., 1986; Dhanoa, 1988):

$$
\mathrm{R}(\mathrm{t})=\mathrm{U}+\mathrm{D} \times \mathrm{e}^{-\mathrm{kd} \times(\mathrm{t}-\mathrm{T} 0)},
$$

where $\mathrm{R}(\mathrm{t})=$ residue at $\mathrm{t}$ hours of incubation (\%), $\mathrm{U}=$ undegradable fraction (\%), $\mathrm{D}=$ potentially degradable fraction (\%), T0 = lag time (h), and $\mathrm{K}_{\mathrm{d}}=$ degradation rate of potentially degradable fraction $(\% / \mathrm{h})$. In situ parameters were calculated with the NLIN (nonlinear) procedure of SAS (SAS Institute, 2009) via the GaussNewton method.

\section{Hourly Effective Degradation Ratio}

Hourly effective degradation (ED) was calculated according to the method of Sinclair et al. (1993):

$$
\mathrm{ED}=\mathrm{S}+\left[\left(\mathrm{D} \times \mathrm{K}_{\mathrm{d}}\right) /\left(\mathrm{K}_{\mathrm{d}}+\mathrm{K}_{\mathrm{p}}\right)\right] \times\left[1-\mathrm{e}^{-\mathrm{t}(\mathrm{Kd}+\mathrm{Kp})}\right],
$$

where $\mathrm{S}=$ washable fraction, and $\mathrm{K}_{\mathrm{p}}=$ passage rate.

The difference of cumulative amounts degraded between successive hours was regarded as the amount of nutrient degraded each hour. The ratio of $\mathrm{N}$ to OM was calculated based on hourly degraded $\mathrm{N}$ and OM:

$$
\begin{gathered}
\text { Hourly ED ratio }\left(\mathrm{N} / \mathrm{OM}_{\mathrm{t}}\right)=\left(\mathrm{HEDN}_{\mathrm{t}}-\mathrm{HEDN}_{\mathrm{t}-1}\right) / \\
\left(\mathrm{HEDOM}_{\mathrm{t}}-\mathrm{HEDOM}_{\mathrm{t}-1}\right)
\end{gathered}
$$

where $\mathrm{N} / \mathrm{OM}_{\mathrm{t}}=$ ratio of $\mathrm{N}$ to $\mathrm{OM}$ at time $\mathrm{t}(\mathrm{g}$ of $\mathrm{N} /$ $\mathrm{kg}$ of $\mathrm{OM}) ; \mathrm{HEDN}_{\mathrm{t}}=$ hourly effective degradability of $\mathrm{N}$ at time $\mathrm{t}(\mathrm{g} / \mathrm{kg}$ of $\mathrm{DM}) ; \mathrm{HEDN}_{\mathrm{t}-1}=$ hourly effective degradability of $\mathrm{N} 1 \mathrm{~h}$ before $\mathrm{t}(\mathrm{g} / \mathrm{kg}$ of DM); HEDOM $=$ hourly effective degradability of $\mathrm{OM}$ at time $\mathrm{t}(\mathrm{g} /$ $\mathrm{kg}$ of DM); and $\mathrm{HEDOM}_{\mathrm{t}-1}=$ hourly effective degradability of OM $1 \mathrm{~h}$ before $\mathrm{t}(\mathrm{g} / \mathrm{kg}$ of $\mathrm{DM})$.

\section{Estimated Intestinal Digestibility of Rumen Undegraded Feed Protein}

Intestinal digestion of rumen undegraded feed protein (\% dRUP) was determined with the 3 -step in vitro procedure described by Calsamiglia and Stern (1995). The dried ground residues of 12 -h rumen incubation time point containing approximately $15 \mathrm{mg}$ of $\mathrm{N}$ were mixed with $10 \mathrm{~mL}$ of $0.1 \mathrm{M} \mathrm{HCl}$ solution containing 1 $\mathrm{g} / \mathrm{L}$ of pepsin. Then samples were incubated in shaking water bath at $38^{\circ} \mathrm{C}$ for $1 \mathrm{~h}$. The $\mathrm{pH}$ was neutralized with $0.5 \mathrm{~mL}$ of $1 \mathrm{M} \mathrm{NaOH}$ and $13.5 \mathrm{~mL}$ of phosphate buffer (pH 7.8) containing $37.5 \mathrm{mg}$ of pancreatin and further incubated at $38^{\circ} \mathrm{C}$ for $24 \mathrm{~h}$. After incubation, to stop the enzymatic reaction, $3 \mathrm{~mL}$ of $100 \%$ (wt/vol) TCA solution was added to precipitate undigested proteins. Samples were centrifuged and supernatant (soluble N) was analyzed for N (Kjeldahl method, AOAC, 1990; method 984.13). Blanks, solution, and enzymes were used to eliminate the background effect. Calculation of intestinally digested protein was done by dividing TCA-soluble $\mathrm{N}$ from the amount of $\mathrm{N}$ in the rumen residue sample.

\section{Metabolic Characteristics of Proteins and Prediction of Nutrient Supply to Dairy Cattle}

The DVE/OEB system was developed to describe the metabolic characteristics of proteins and to predict truly digested and absorbed protein supply to dairy cows (Tamminga et al., 1994, 2007). This system is composed of 2 major parts, which describe a DVE value and an OEB value for a feed (Tamminga et al., 1994, 2007). Feed DVE value is truly absorbed protein value which consists of (1) rumen undegraded feed protein that absorbs in small intestine as amino acids (ARUP), the microbial protein synthesized in rumen and absorbed in small intestine as amino acid (AMCP), and correction for endogenous losses resulting from digestion (ENDP), calculated as follows: DVE $(\mathrm{g} / \mathrm{kg}$ DM $)=$ AMCP + ARUP - ENDP.

Microbial protein production is based on the fermentable organic matter (FOM) content in the DVE/OEB system. The FOM is calculated from digestible organic matter (DOM) but DOM is corrected for CFat, rumen undegraded feed protein (RUP), undegraded starch (RUST), and $50 \%$ of the fermentation end-products in ensiled products.

In the DVE/OEB system, AMCP was calculated as follows: $\mathrm{AMCP}(\mathrm{g} / \mathrm{kg} \mathrm{DM})=\mathrm{FOM} \times 0.150 \times 0.75$ $\times 0.85$, with the assumption that $150 \mathrm{~g}$ of $\mathrm{MCP}$ is produced from $1 \mathrm{~kg}$ of $\mathrm{FOM}$, and where true protein is assumed to be $75 \%$ with $85 \%$ digestibility in the small intestine. The absorbed rumen undegraded feed protein is calculated as follows: ARUP $(\mathrm{g} / \mathrm{kg} \mathrm{DM})=\mathrm{CP} \times$ $(1.11 \times \mathrm{RUP}) \times(\% \mathrm{dRUP} / 100)$. The correction for endogenous losses in digestion is calculated as follows: $\operatorname{ENDP}(\mathrm{g} / \mathrm{kg} \mathrm{DM})=0.075 \times \mathrm{UDM}(\mathrm{g} / \mathrm{kg} \mathrm{DM})$, where UDM is the combination of both organic and inorganic indigestible matter and calculated thus: UDM $(\mathrm{g} / \mathrm{kg}$ 
$\mathrm{DM})=1,000-\mathrm{DOM}-$ VRAS, where VRAS is digestible inorganic matter.

The degraded protein balance is a new concept introduced by the DVE/OEB system and concerns the balance between microbial protein synthesis in the rumen from available rumen degradable protein (RDP) and potential energy from anaerobic fermentation in the rumen. The degraded protein balance value is estimated as $\mathrm{OEB}(\mathrm{g} / \mathrm{kg} \mathrm{DM})=\mathrm{MCP}_{\mathrm{RDP}}-\mathrm{MCP}_{\mathrm{FOM}}$, where $\mathrm{MCP}_{\mathrm{RDP}}$ is microbial $\mathrm{CP}$ based on RDP, and $\mathrm{MCP}_{\mathrm{FOM}}$ is microbial CP based on FOM. The DVE/ OEB system recommends that the OEB value not be negative in dairy cow rations due to the possibility of $\mathrm{N}$ shortage for microbial protein synthesis.

\section{Statistical Analysis}

Statistical analyses were performed using the Mixed procedure of SAS 9.2 (SAS Institute, 2009).

Chemical Profile. The model used for the analysis was $Y_{i j}=\mu+t_{i}+e_{i j}$, where $\mu$ is the overall mean, $t_{i}$ is the fixed effect of treatment ( $\mathrm{i}=1,2$, feedstock of wheat vs. wDDGS; $\mathrm{i}=1$ to 5 as the wheat batches, or $\mathrm{i}=\mathrm{I}$ to $\mathrm{V}$ as the wDDGS batches), and $\mathrm{e}_{\mathrm{ij}}$ is the associated error.

Rumen and Intestinal Digestion and Predicted Nutrient Supply. The model used for the analysis was $Y_{i j k}=\mu+B_{i}+R_{j}+e_{i j k}$, where $\mu$ is the overall mean, $B_{i}$ is the fixed effect of treatment $(i=1,2$, the feedstock of wheat vs. wDDGS, $\mathrm{i}=1$ to 5 as the wheat batches, or $\mathrm{i}=\mathrm{I}$ to $\mathrm{V}$ as ${ }^{\mathrm{wDDGS}}$ batches), $\mathrm{R}_{\mathrm{j}}$ is the experimental run as a random effect, and $e_{i j k}$ is the associated error.

The normality test to check the analysis model assumptions in the above models was performed using Proc Univariate with plot and normal options. For all statistical analyses, significance was declared at $P<$ 0.05. The Tukey method was used for multi-treatment comparison. Means with different superscript letter groups were obtained with "pdmix800 SAS macro" (Saxton, 1998).

Molecular Spectral Profile in Feedstock and Co-Products. Multivariate analyses of spectra were carried out using Statistica 7.0 software (StatSoft Inc., Tulsa, OK). The different batches of the wheat and corresponding wDDGS were compared in the molecular spectral profiles. For AHCA and PCA analyses, the spectral region of $\sim 1,800$ to $800 \mathrm{~cm}^{-1}$ (fingerprint region) was used, which contains most important chemical functional groups in biological materials (Wetzel et al., 1998).

$\boldsymbol{A H C A}$. Results of AHCA are displayed as dendrograms. The technique calculates the distance matrix for the 2 most similar IR spectra by algorithm searches. The similar spectra collectively are called clusters or hierarchical groups. Then, the distances for the remaining spectra are calculated from the newly formed cluster (Cytospec, 2004; Yu, 2005). Ward's algorithm and Euclidian distance methods were applied in this study (Yu, 2005).

$\boldsymbol{P C A}$. Principal component analysis is a statistical data reduction method that converts the original set of IR variables to a new set of summarized IR variables called principal components (PC). The first derived IR $\mathrm{PC}$ contains more variability and with the extraction of more IR factors, variability becomes less. These IR factors are independent from each other (Sockalingum et al., 1998; Yu, 2005). The results of PCA spectral analysis can be presented as 2-dimensional or 3-dimensional scattered plots.

\section{RESULTS AND DISCUSSION}

\section{Chemical Profiles in Different Batches of Wheat and wDDGS}

The feedstock of wheat had lower $(P<0.05)$ DM, ash, and CFat than their co-products (wDDGS; Table $1)$. As expected, the wheat contained higher $(P<0.05)$ starch, whereas the wDDGS contained higher $(P<$ 0.05) NDF, ADF, ADL, cellulose, and hemicellulose (Table 1). The wDDGS were higher in CP, SCP, NPN, ADICP, and NDICP compared with the feedstock (Table 1). The SCP in the wDDGS consisted mainly of NPN (91.5 vs. $30.4 \%$ SCP in wheat), similar to findings of Nuez-Ortín and Yu (2009). The DM, CP, and NDF values obtained for wheat were in close agreement with the values reported in NRC (2001). The chemical profile of the wDDGS in this study was in close agreement with the values reported in published studies (Thacker and Widyaratne, 2007; Widyaratne and Zijlstra, 2007; Nuez-Ortín and Yu, 2009).

Among the 5 batches of wheat, ADF values were lower than previously reported values (Nuez-Ortín and $\mathrm{Yu}, 2009)$, with the highest ADF value being in batch 4 and the lowest in batch 2 (Table 1). Wheat batch 3 was lower in NDF and CP than were wheat batches 1 and 4 . The range of NPN among the wheat batches was large (25.4\% on SCP basis), which might be due to the wheat sources collected by the bioethanol plant.

We observed significant differences $(P<0.05)$ between the batches of wDDGS in DM, ash, NDF, and ADF. The NPN on an SCP basis and ADICP on a $\mathrm{CP}$ were similar among the 5 batches of wDDGS. The obtained values for wDDGS are in close agreement with the values previously reported (Boila and Ingalls, 
Table 1. Chemical characterization in different batches of feedstock (wheat) for bioethanol production and their co-products (wheat distillers dried grains with solubles, wDDGS) from the same bioethanol processing plant

\begin{tabular}{|c|c|c|c|c|c|c|c|c|c|c|c|c|c|c|c|}
\hline \multirow[b]{2}{*}{ Item } & \multirow[b]{2}{*}{$\begin{array}{l}\text { Wheat } \\
(\mathrm{n}=15)\end{array}$} & \multirow[b]{2}{*}{$\begin{array}{l}\text { wDDGS } \\
(\mathrm{n}=15)\end{array}$} & \multirow[b]{2}{*}{ SEM } & \multicolumn{5}{|c|}{ Wheat } & \multirow[b]{2}{*}{ SEM } & \multicolumn{5}{|c|}{ wDDGS } & \multirow[b]{2}{*}{ SEM } \\
\hline & & & & $\left(\begin{array}{c}1 \\
(\mathrm{n}=3)\end{array}\right.$ & $\left(\begin{array}{c}2 \\
(\mathrm{n}=3)\end{array}\right.$ & $\begin{array}{c}3 \\
(\mathrm{n}=3)\end{array}$ & $\begin{array}{c}4 \\
(\mathrm{n}=3)\end{array}$ & $\begin{array}{c}5 \\
(\mathrm{n}=3)\end{array}$ & & $\left(\begin{array}{c}\mathrm{I} \\
(\mathrm{n}=3)\end{array}\right.$ & $\begin{array}{c}\mathrm{II} \\
(\mathrm{n}=3)\end{array}$ & $\begin{array}{c}\text { III } \\
(\mathrm{n}=3)\end{array}$ & $\begin{array}{c}\mathrm{IV} \\
(\mathrm{n}=3)\end{array}$ & $\begin{array}{c}\mathrm{V} \\
(\mathrm{n}=3)\end{array}$ & \\
\hline \multicolumn{16}{|c|}{ Basic chemical profile ${ }^{1}$} \\
\hline $\mathrm{DM}(\%)$ & $88.3^{\mathrm{b}}$ & $92.4^{\mathrm{a}}$ & 0.17 & $88.2^{\mathrm{ab}}$ & $88.3^{\mathrm{ab}}$ & $88.7^{\mathrm{a}}$ & $87.9^{\mathrm{b}}$ & $88.3^{\mathrm{ab}}$ & 0.13 & $92.7^{\mathrm{ab}}$ & $93.2^{\mathrm{a}}$ & $91.6^{\mathrm{b}}$ & $92.9^{\mathrm{ab}}$ & $91.6^{\mathrm{b}}$ & 0.33 \\
\hline Ash $(\%$ of DM) & $1.9^{\mathrm{b}}$ & $5.7^{\mathrm{a}}$ & 0.08 & 1.8 & 1.8 & 1.8 & 2.0 & 2.0 & 0.07 & $5.3^{\mathrm{c}}$ & $6.2^{\mathrm{a}}$ & $5.4^{\mathrm{c}}$ & $6.1^{\mathrm{a}}$ & $5.7^{\mathrm{b}}$ & 0.03 \\
\hline $\mathrm{OM}(\%$ of DM) & $98.1^{\mathrm{a}}$ & $94.3^{\mathrm{b}}$ & 0.08 & 98.2 & 98.2 & 98.2 & 98.1 & 98.0 & 0.07 & $94.7^{\mathrm{a}}$ & $93.8^{\mathrm{c}}$ & $94.6^{\mathrm{a}}$ & $93.9^{\mathrm{c}}$ & $94.4^{\mathrm{b}}$ & 0.03 \\
\hline CFat (\% of DM) & $1.4^{\mathrm{b}}$ & $5.1^{\mathrm{a}}$ & 0.05 & 1.2 & 1.4 & 1.6 & 1.5 & 1.5 & 0.11 & 5.2 & 5.1 & 5.2 & 5.2 & 5.0 & 0.08 \\
\hline \multicolumn{16}{|c|}{ Structural carbohydrate profile (\% of DM) } \\
\hline NDF & $13.9^{\mathrm{b}}$ & $39.8^{\mathrm{a}}$ & 0.45 & $14.1^{\mathrm{ab}}$ & $13.3^{\mathrm{bc}}$ & $12.6^{\mathrm{c}}$ & $15.1^{\mathrm{a}}$ & $14.1^{\mathrm{ab}}$ & 0.30 & $38.4^{\mathrm{b}}$ & $37.2^{\mathrm{b}}$ & $39.3^{\mathrm{b}}$ & $41.9^{\mathrm{a}}$ & $42.4^{\mathrm{a}}$ & 0.53 \\
\hline $\mathrm{ADF}$ & $3.0^{\mathrm{b}}$ & $11.6^{\mathrm{a}}$ & 0.32 & $2.7^{\mathrm{bc}}$ & $2.5^{\mathrm{c}}$ & $2.7^{\mathrm{bc}}$ & $3.5^{\mathrm{a}}$ & $3.4^{\mathrm{ab}}$ & 0.16 & $10.1^{\mathrm{b}}$ & $10.8^{\mathrm{b}}$ & $10.6^{\mathrm{b}}$ & $12.9^{\mathrm{a}}$ & $13.9^{\mathrm{a}}$ & 0.44 \\
\hline ADL & $0.8^{\mathrm{b}}$ & $3.1^{\mathrm{a}}$ & 0.16 & $0.5^{\mathrm{b}}$ & $0.5^{\mathrm{b}}$ & $0.5^{\mathrm{b}}$ & $1.1^{\mathrm{a}}$ & $1.1^{\mathrm{a}}$ & 0.07 & $2.15^{\mathrm{c}}$ & $2.9^{\mathrm{bc}}$ & $2.6^{\mathrm{c}}$ & $3.5^{\mathrm{b}}$ & $4.4^{\mathrm{a}}$ & 0.17 \\
\hline Hemicelluloses & $11.0^{\mathrm{b}}$ & $28.2^{\mathrm{a}}$ & 0.27 & $11.5^{\mathrm{ab}}$ & $10.9^{\mathrm{ab}}$ & $9.9^{\mathrm{b}}$ & $11.9^{\mathrm{a}}$ & $11.0^{\mathrm{ab}}$ & 0.39 & $28.2^{\mathrm{a}}$ & $26.4^{\mathrm{b}}$ & $28.7^{\mathrm{ab}}$ & $29.0^{\mathrm{a}}$ & $28.5^{\mathrm{ab}}$ & 0.50 \\
\hline Cellulose & $2.2^{\mathrm{b}}$ & $8.5^{\mathrm{a}}$ & 0.17 & 2.2 & 2.0 & 2.2 & 2.4 & 2.3 & 0.11 & $7.9^{\mathrm{b}}$ & $7.9^{\mathrm{b}}$ & $7.9^{\mathrm{b}}$ & $9.4^{\mathrm{a}}$ & $9.5^{\mathrm{a}}$ & 0.30 \\
\hline \multicolumn{16}{|l|}{ NSC profile } \\
\hline Starch (\% of DM) & $63.4^{\mathrm{a}}$ & $1.8^{\mathrm{b}}$ & 0.54 & 61.6 & 66.4 & 62.9 & 63.0 & 63.4 & 1.65 & $1.6^{\mathrm{b}}$ & $1.4 \mathrm{c}$ & $2.6^{\mathrm{a}}$ & $1.5^{\mathrm{bc}}$ & $1.7^{\mathrm{b}}$ & 0.06 \\
\hline CP (\% of DM) & $14.3^{\mathrm{b}}$ & $42.8^{\mathrm{a}}$ & 0.31 & $15.1^{\mathrm{a}}$ & $14.4^{\mathrm{b}}$ & $13.0^{\mathrm{c}}$ & $14.7^{\mathrm{ab}}$ & $14.4^{\mathrm{b}}$ & 0.64 & $44.9^{\mathrm{a}}$ & $43.9^{\mathrm{a}}$ & $42.0^{\mathrm{b}}$ & $41.0^{\mathrm{b}}$ & $42.2^{\mathrm{b}}$ & 0.26 \\
\hline $\mathrm{SCP}(\%$ of $\mathrm{CP})$ & $27.0^{\mathrm{b}}$ & $34.8^{\mathrm{a}}$ & 0.59 & $27.2^{\mathrm{bc}}$ & $28.3^{\mathrm{ab}}$ & $30.7^{\mathrm{a}}$ & $23.5^{\mathrm{d}}$ & $25.0^{\mathrm{cd}}$ & 0.44 & $34.6^{\mathrm{a}}$ & $35.3^{\mathrm{a}}$ & $32.3^{\mathrm{b}}$ & $36.5^{\mathrm{a}}$ & $35.5^{\mathrm{a}}$ & 0.47 \\
\hline NPN (\% of SCP) & $30.4^{\mathrm{b}}$ & $91.5^{\mathrm{a}}$ & 2.00 & $41.1^{\mathrm{a}}$ & $31.3^{\mathrm{ab}}$ & $15.7^{\mathrm{b}}$ & $33.4^{\mathrm{ab}}$ & $30.2^{\mathrm{ab}}$ & 3.87 & 87.3 & 94.1 & 94.8 & 91.3 & 90.1 & 1.67 \\
\hline NPN ( $\%$ of CP) & $10.5^{\mathrm{b}}$ & $31.8^{\mathrm{a}}$ & 1.00 & $11.1^{\mathrm{b}}$ & $8.9^{\mathrm{b}}$ & $4.8^{\mathrm{c}}$ & $7.9^{\mathrm{bc}}$ & $19.6^{\mathrm{a}}$ & 0.75 & $30.2^{\mathrm{b}}$ & $33.2^{\mathrm{a}}$ & $30.6^{\mathrm{b}}$ & $33.3^{\mathrm{a}}$ & $32.0^{\mathrm{ab}}$ & 0.49 \\
\hline NDICP (\% of CP) & $10.3^{\mathrm{b}}$ & $37.3^{\mathrm{a}}$ & 0.65 & $13.3^{\mathrm{a}}$ & $11.1^{\mathrm{ab}}$ & $11.0^{\mathrm{ab}}$ & $9.2^{\mathrm{bc}}$ & $7.1^{\mathrm{c}}$ & 0.52 & $35.4^{\mathrm{b}}$ & $39.6^{\mathrm{a}}$ & $43.3^{\mathrm{a}}$ & $41.3^{\mathrm{a}}$ & $42.5^{\mathrm{a}}$ & 0.81 \\
\hline $\mathrm{ADICP}(\%$ of $\mathrm{CP})$ & $1.1^{\mathrm{b}}$ & $3.5^{\mathrm{a}}$ & 0.40 & $0.2^{\mathrm{c}}$ & $0.2^{\mathrm{c}}$ & $0.1^{\mathrm{c}}$ & $3.7^{\mathrm{a}}$ & $1.4^{\mathrm{b}}$ & 0.21 & 3.4 & 5.1 & 2.7 & 4.1 & 2.3 & 0.85 \\
\hline
\end{tabular}

${ }^{a-d}$ Means with different superscript letters in the same row are significantly different $(P<0.05)$.

${ }^{1} \mathrm{CFat}=$ crude fat $($ ether extract).

${ }^{2} \mathrm{SCP}=$ bicarbonate phosphate buffer soluble $\mathrm{CP} ; \mathrm{NPN}=$ nitrogenous compounds soluble in water and not precipitated by TCA; NDICP $=$ neutral detergent insoluble CP; ADICP $=$ acid detergent insoluble $\mathrm{CP}$. 
1994a,b; Widyaratne and Zijlstra, 2007; Gibb et al., 2008; Nuez-Ortín and Yu, 2009). Among the co-products, wDDGS batch IV had the lowest CP and batch I had the highest $\mathrm{CP}(P<0.05)$. The NDF value varied among batches of wDDGS by $5.1 \%$ DM $(P<0.05)$. The high ADICP levels in cottonseed meal (Arieli et al., 1989) and canola meal (Nia and Ingalls, 1992) were reported to be due to high temperature treatment during processing. The high level of ADICP in wDDGS from bioethanol processing may be due not only to dry processing with high temperatures but also to fermentation processing and amount of solubles added back.

The wDDGS did not have the same pattern of variation among the batches as their parent feedstock of wheat. The magnitude of differences among wDDGS was different from the magnitude of differences among the wheat batches. Therefore, the wheat batches were not the only factor to cause variation among the batches of wDDGS. The bioethanol process may also play a role in causing differences among the batches of wDDGS. Belyea et al. (2006) reported that factors other than the original feedstock grain cause the variation among the batches of corn DDGS, such as factors associated with bioethanol production processes.

\section{Mineral Profiles in Different Batches of Wheat and wDDGS}

In the current literature, information is scarce regarding the micro- and macromineral profiles of co-products from bioethanol processing. Mineral composition in dairy cattle diet is critical because excesses or deficits in the required amount of minerals can lead to various metabolic disorders. Other than the adverse effects on the animal, excessive mineral consumption leads to increased excretion of minerals to the environment (Spiehs and Varel, 2009). The average values of calcium for wheat and wDDGS were 0.05 and $0.10 \%$ of DM, respectively. The contents of phosphorus, magnesium, and sulfur were significantly different $(P<0.05)$ among the wheat and wDDGS batches (Table 2). Among the wheat batches, the range of phosphorus was $0.08 \%$ of DM, whereas the range among the batches of wDDGS was $0.05 \%$ of DM. The contents of both calcium and phosphorus are in agreement with the values given by NRC (2001) for the co-product wDDGS. Furthermore, NRC (2001) identifies phosphorus as the most vulnerable mineral to be in excess for the animal, with a much higher possibility of contaminating the environment, especially the surface water. The highest proportion of absorbed phosphorus in dairy cattle is directed into milk phosphorus (NRC, 2001). The NRC (2001) model recommends the phosphorus content of a diet to be between 0.30 and $0.40 \%$ of diet DM, depending on the level of milk production. The range of sulfur content among the wheat batches was $0.03 \%$, whereas the range among batches of wDDGS was $0.34 \%$. The average value obtained for the sulfur content in the wDDGS was $0.65 \%$ DM higher (1.09 vs. $0.44 \%$ of DM) than that given by NRC (2001) for wDDGS. The excess intake of sulfur by beef cattle fed a diet containing $0.5 \%$ sulfur resulted in the occurrence of polioencephalomalacia (McAllister et al., 1997). The addition of various chemicals during bioethanol processing causes an increase in mineral content and high variation in mineral profiles (Batal and Dale, 2003; Belyea et al., 2006; Liu and Han, 2011). Thin stillage obtained after centrifugation of whole stillage was found to have a concentrated mineral content (Liu and Han, 2011). The uneven mixing of different proportions of thin stillage and distillers grain might explain the variation among different batches of wDDGS. The study carried out by Rausch and Belyea (2006) found changes in mineral composition during the dry grinding process due to the addition of exogenous minerals in the bioethanol production process. We observed significant differences $(P$ $<0.05)$ between the wheat and wDDGS in micromineral composition. Among the wheat batches, manganese and iron contents had a range of 14.1 and $40.6 \mathrm{mg} /$ $\mathrm{kg}$ of DM, respectively. Among the wDDGS batches, zinc, manganese, and iron contents had a range of 18.4, 9.6 , and $100 \mathrm{mg} / \mathrm{kg}$ of DM, respectively. Consideration of the mineral composition of the amount of wDDGS to be used in the daily ration is necessary to avoid environmental contamination and health problems in the animals.

\section{Protein and Carbohydrate Subfractions in Different Batches of Wheat and wDDGS}

Proteins and carbohydrates were fractionated according to CNCPS (Sniffen et al., 1992; Chalupa and Sniffen, 1994). The CNCPS protein and carbohydrate fractions are closely related to rumen degradation behavior and indicate the nutrient availability to the animal. In carbohydrate and protein subfractions, we found significant differences between batches of wheat and wDDGS $(P<0.05$; Table 3$)$. The rapidly degradable PA fraction (NPN) was 3 times higher in wDDGS than in wheat. The wheat contained 5 times more rapidly degradable true protein fraction (PB1) compared with wDDGS. Wheat batch 3 contained the most PB1 and batch 5 contained the least (5 times lower than batch 3). Wheat batches 1 to 3 had lower intermediately degradable fraction (PB2; average of $57.9 \%$ of $\mathrm{CP}$ ) relative to wheat batches 4 and 5 (average of $67.6 \%$ 
of $\mathrm{CP}$ ). Wheat batch 4 had the highest unavailable fraction (PC). In the wDDGS, the rapidly degradable fraction $\mathrm{PB} 1$ ranged from $1.7 \%$ of $\mathrm{CP}$ in batch III to $4.4 \%$ of $\mathrm{CP}$ in batch I. The increased PB3 and PC fractions in wDDGS compared with wheat might be caused by denaturation and heating of protein during the drying process (Goelema, 1999), which increased the more slowly degradable fractions, or it is because microbes in bio-ethanol fermentation utilize the easily fermentable protein, which leaves less fermentable (PB3 and PC) in the feed. The increased slowly degradable fractions in the wDDGS make it less available for microbial degradation in the rumen (Kleinschmit et al., 2007; Nuez-Ortín and Yu, 2009). Among the wDDGS, PB2 varied from 25.2 to $32.6 \%$ of $\mathrm{CP}$ and $\mathrm{PB} 3$ varied from 29.5 to $36.9 \%$ of CP.

Carbohydrate subfractions differed between the wheat and wDDGS and among different wheat and wDDGS batches $(P<0.05$; Table 3$)$. Compared with wDDGS, wheat contained a higher $(P<0.05)$ total $\mathrm{CHO}$ fraction, lower sugar $(\mathrm{CA})$ fraction, and higher starch- and pectin-containing (CB1) fraction. The wDDGS was higher in available cell wall (CB2) fraction and unavailable fiber $(\mathrm{CC})$ fraction compared with the wheat. The 5 wheat batches had similar fast degradable CHO CB1 fraction with an average of $75.6 \%$ CHO. Among the wheat batches, the range for CB2 was $2.1 \%$ $\mathrm{CHO}$ and for $\mathrm{CC}$ was $1.8 \% \mathrm{CHO}(P<0.05)$. The sugar CA fractions were higher in wDDGS batch II $(P<$ 0.05) compared with batches IV and V. Batch III of wDDGS contained more $(P<0.05)$ CB1 compared with the other batches. The CB2 fraction was higher in batch I $(P<0.05)$ compared with batches II, III, and $\mathrm{V}$. The CC fraction was significantly different among the batches of wDDGS, with the highest CC in batch V and a range of $10.8 \% \mathrm{CHO}$. These results indicated that origins of wheat and batches of wDDGS had significant effects on $\mathrm{CHO}$ subfraction profile, rumen fermentation behaviors, and nutrient availability and supply to small intestine.

\section{Energy Content in Different Batches of Wheat and wDDGS}

The feedstock of wheat was higher in tdNFC $(P$ $<0.05)$, whereas wDDGS was higher in tdCP, tdFA, and tdNDF $(P<0.05$; Table 4$)$. The highest tdNFC and tdCP were in wheat batches 3 and 1, respectively. The highest tdNFC was in wDDGS batches II and III, whereas batch I contained the highest tdCP and tdNDF values. Wheat had higher TDN content $(P<$ 0.05) compared with wDDGS (Table 4). Among the batches of wheat, the difference among $\mathrm{TDN}_{1 \times}$ values was $1.5 \%$ of DM. In the wDDGS, batches I and III 
Table 3. Protein and carbohydrate (CHO) subfractions that are associated with different rumen degradation in different batches of feedstock for bioethanol production (wheat) and their co-products (wheat distillers dried grains with solubles, wDDGS) from the same bioethanol processing plant

\begin{tabular}{|c|c|c|c|c|c|c|c|c|c|c|c|c|c|c|c|}
\hline \multirow[b]{2}{*}{ Item } & \multirow[b]{2}{*}{$\begin{array}{l}\text { Wheat } \\
(\mathrm{n}=15)\end{array}$} & \multirow[b]{2}{*}{$\begin{array}{l}\text { wDDGS } \\
(\mathrm{n}=15)\end{array}$} & \multirow[b]{2}{*}{ SEM } & \multicolumn{5}{|c|}{ Wheat } & \multirow[b]{2}{*}{ SEM } & \multicolumn{5}{|c|}{ wDDGS } & \multirow[b]{2}{*}{ SEM } \\
\hline & & & & $\begin{array}{c}1 \\
(\mathrm{n}=3)\end{array}$ & $\begin{array}{c}2 \\
(\mathrm{n}=3)\end{array}$ & $\begin{array}{c}3 \\
(\mathrm{n}=3)\end{array}$ & $\begin{array}{c}4 \\
(\mathrm{n}=3)\end{array}$ & $\begin{array}{c}5 \\
(\mathrm{n}=3)\end{array}$ & & $\begin{array}{c}\mathrm{I} \\
(\mathrm{n}=3)\end{array}$ & $\begin{array}{c}\mathrm{II} \\
(\mathrm{n}=3)\end{array}$ & $\begin{array}{c}\mathrm{III} \\
(\mathrm{n}=3)\end{array}$ & $\begin{array}{c}\mathrm{IV} \\
(\mathrm{n}=3)\end{array}$ & $\begin{array}{c}\mathrm{V} \\
(\mathrm{n}=3)\end{array}$ & \\
\hline \multicolumn{16}{|c|}{ Protein subfractions $^{1}(\%$ of $\mathrm{CP})$} \\
\hline PA & $10.5^{\mathrm{b}}$ & $31.8^{\mathrm{a}}$ & 1.00 & $11.1^{\mathrm{b}}$ & $8.9^{\mathrm{b}}$ & $4.8^{\mathrm{c}}$ & $7.9^{\mathrm{bc}}$ & $19.6^{\mathrm{a}}$ & 0.75 & $30.2^{\mathrm{b}}$ & $33.2^{\mathrm{a}}$ & $30.6^{\mathrm{b}}$ & $33.3^{\mathrm{a}}$ & $32.0^{\mathrm{ab}}$ & 0.49 \\
\hline PB1 & $16.5^{\mathrm{a}}$ & $3.0^{\mathrm{b}}$ & 1.32 & $16.2^{\mathrm{b}}$ & $19.5^{\mathrm{b}}$ & $25.9^{\mathrm{a}}$ & $15.7^{\mathrm{b}}$ & $5.4^{\mathrm{c}}$ & 1.18 & 4.4 & 2.1 & 1.7 & 3.2 & 3.5 & 0.60 \\
\hline PB2 & $62.7^{\mathrm{a}}$ & $27.9^{\mathrm{b}}$ & 0.95 & $59.5^{\mathrm{b}}$ & $60.6^{\mathrm{b}}$ & $58.3^{\mathrm{b}}$ & $67.3^{\mathrm{a}}$ & $67.9^{\mathrm{a}}$ & 0.60 & $32.6^{\mathrm{a}}$ & $27.8^{\mathrm{b}}$ & $28.1^{\mathrm{b}}$ & $25.2^{\mathrm{b}}$ & $25.6^{\mathrm{b}}$ & 0.74 \\
\hline PB3 & $9.2^{\mathrm{b}}$ & $33.8^{\mathrm{a}}$ & 0.87 & $13.1^{\mathrm{a}}$ & $10.9^{\mathrm{a}}$ & $10.8^{\mathrm{a}}$ & $5.5^{\mathrm{b}}$ & $5.7^{\mathrm{b}}$ & 0.51 & $29.5^{\mathrm{b}}$ & $31.8^{\mathrm{ab}}$ & $36.9^{\mathrm{a}}$ & $34.2^{\mathrm{ab}}$ & $36.6^{\mathrm{a}}$ & 1.30 \\
\hline $\mathrm{PC}$ & $1.1^{\mathrm{b}}$ & $3.5^{\mathrm{a}}$ & 0.40 & $0.2^{\mathrm{c}}$ & $0.2^{\mathrm{c}}$ & $0.1^{\mathrm{c}}$ & $3.7^{\mathrm{a}}$ & $1.4^{\mathrm{b}}$ & 0.21 & 3.4 & 5.1 & 2.7 & 4.1 & 2.3 & 0.85 \\
\hline $\mathrm{TP}$ & $88.4^{\mathrm{a}}$ & $64.6^{\mathrm{b}}$ & 1.11 & $88.7^{\mathrm{b}}$ & $91.0^{\mathrm{b}}$ & $95.1^{\mathrm{a}}$ & $88.5^{\mathrm{b}}$ & $79.0^{\mathrm{c}}$ & 0.68 & $66.4^{\mathrm{ab}}$ & $61.7^{\mathrm{c}}$ & $66.7^{\mathrm{a}}$ & $62.6^{\mathrm{bc}}$ & $65.8^{\mathrm{ab}}$ & 0.84 \\
\hline \multicolumn{16}{|c|}{ CHO subfractions ${ }^{2}$ ( $\%$ of $\mathrm{CHO}$ ) } \\
\hline $\mathrm{CHO}(\%$ of $\mathrm{DM})$ & $82.4^{\mathrm{a}}$ & $46.4^{\mathrm{b}}$ & 0.30 & $81.9^{\mathrm{b}}$ & $82.4^{\mathrm{b}}$ & $83.7^{\mathrm{a}}$ & $81.8^{\mathrm{b}}$ & $82.1^{\mathrm{b}}$ & 0.16 & $44.7^{\mathrm{b}}$ & $44.8^{\mathrm{b}}$ & $47.5^{\mathrm{a}}$ & $47.6^{\mathrm{a}}$ & $47.2^{\mathrm{a}}$ & 0.26 \\
\hline $\mathrm{CA}$ & $9.9^{\mathrm{b}}$ & $45.0^{\mathrm{a}}$ & 0.66 & 10.3 & 8.6 & 11.6 & 9.3 & 9.4 & 1.37 & $44.0^{\mathrm{b}}$ & $50.1^{\mathrm{a}}$ & $47.2^{\mathrm{ab}}$ & $42.0^{\mathrm{b}}$ & $41.4^{\mathrm{b}}$ & 1.27 \\
\hline CB1 & $74.7^{\mathrm{a}}$ & $3.6^{\mathrm{b}}$ & 0.15 & 74.8 & 76.6 & 75.0 & 73.4 & 74.4 & 1.53 & $3.3^{\mathrm{b}}$ & $3.0^{\mathrm{b}}$ & $5.2^{\mathrm{a}}$ & $3.1^{\mathrm{b}}$ & $3.4^{\mathrm{b}}$ & 0.12 \\
\hline CB2 & $13.1^{\mathrm{b}}$ & $35.4^{\mathrm{a}}$ & 0.57 & $13.4^{\mathrm{ab}}$ & $13.1^{\mathrm{ab}}$ & $11.9^{\mathrm{b}}$ & $13.9^{\mathrm{a}}$ & $13.2^{\mathrm{ab}}$ & 0.12 & $41.1^{\mathrm{a}}$ & $31.5^{\mathrm{c}}$ & $34.4^{\mathrm{bc}}$ & $37.4^{\mathrm{ab}}$ & $32.9^{\mathrm{bc}}$ & 1.07 \\
\hline $\mathrm{CC}$ & $2.3^{\mathrm{b}}$ & $16.0^{\mathrm{a}}$ & 0.62 & $1.5^{\mathrm{b}}$ & $1.7^{\mathrm{b}}$ & $1.6^{\mathrm{b}}$ & $3.3^{\mathrm{a}}$ & $3.1^{\mathrm{a}}$ & 0.05 & $11.5^{\mathrm{c}}$ & $15.4^{\mathrm{bc}}$ & $13.3^{\mathrm{c}}$ & $17.6^{\mathrm{b}}$ & $22.3^{\mathrm{a}}$ & 0.84 \\
\hline
\end{tabular}

${ }^{\mathrm{a}-\mathrm{c}}$ Mean with different superscript letters in the same row are significantly different $(P<0.05)$.

${ }^{1} \mathrm{PA}=$ fraction of $\mathrm{CP}$ that is instantaneously solubilized at time zero, calculated as NPN; PB1 = rapidly degradable protein fraction that is soluble in borate phosphate buffer and precipitated with TCA, calculated as soluble $\mathrm{CP}(\mathrm{SCP})$ minus NPN; $\mathrm{PB} 2=$ intermediately degradable protein fraction calculated as total $\mathrm{CP}$ minus the sum of fractions $\mathrm{PA}$, $\mathrm{PB} 1$, $\mathrm{PB} 3$, and PC; PB3 = slowly degradable protein fraction, calculated as neutral detergent insoluble CP minus acid detergent insoluble CP; PC = fraction of undegradable protein, calculated as ADICP. It contained the proteins associated with lignin and tannins and heat-damaged proteins such as Maillard reaction products; TP = true protein, calculated as $\mathrm{TP}=\mathrm{PB} 1+\mathrm{PB} 2+\mathrm{PB} 3$; total carbohydrates $(\mathrm{CHO})=100-\mathrm{CP}-$ crude fat - ash .

${ }^{2} \mathrm{CHO}=100-\mathrm{CP}$ - ether extract - ash; $\mathrm{CA}=$ fraction of total $\mathrm{CHO}$ with a rapid fractional degradation rate, $\mathrm{K}_{\mathrm{d}}(300 \% / \mathrm{h})$, and is degradable soluble sugars and organic acids, calculated as NFC minus CB1; CB1 = fraction of total CHO with an intermediate $\mathrm{K}_{\mathrm{d}}(20-50 \% / \mathrm{h}$ ) and is starch and pectin, calculated as N-adjusted NDF (NDFn) minus CC; $\mathrm{CB} 2=$ fraction of total carbohydrate with a slow $\mathrm{K}_{\mathrm{d}}(2-10 \% / \mathrm{h})$ and is available cell wall; $\mathrm{CC}=$ fraction of total carbohydrate and is unavailable cell wall and not fermented, and is calculated as 0.024 times ADL. 
had the highest $\mathrm{TDN}_{1 \times}$ value and batches IV and V the lowest. The calculated values for $\mathrm{DE}_{3 \times}, \mathrm{ME}_{3 \times}$, and $\mathrm{NE}_{\mathrm{L} 3 \times}$ in this study closely agreed with the values reported by Nuez-Ortín and Yu (2009), which were 3.39, 2.97, and 1.89 for wheat and $3.42,3.01$, and 1.94 for wDDGS, respectively.

\section{Rumen Degradation Kinetics in Different Batches of Wheat and wDDGS}

Geometric mean of particle size varied among the wheat batches, from 1,629 to $1,756 \mu \mathrm{m}$, and among the batches of wDDGS, from 650 to $690 \mu \mathrm{m}$ (Table 5). Usually, the small particle size of co-product is considered to have a negative effect on rumen digestive characteristics (Belyea et al., 2004) because it will result in very high rumen degradation rate and extent.

In Situ Rumen Degradation Kinetics of DM and $\boldsymbol{O M}$. The feedstock of wheat was lower in $\mathrm{S}$ and $\mathrm{U}$ and higher in D for both DM and OM compared with wDDGS $(P<0.05$; Table 5$)$. The degradation rate $\left(\mathbf{K}_{\mathrm{d}}\right)$ in the wheat was 2 times higher than that in the wDDGS. The lower washout fraction $(\mathrm{S})$ of the wheat may be due to its particle size when processed coarsely with the roller gap of $0.203 \mathrm{~mm}$. The mash type of wDDGS had a finer particle size $(\sim 43 \%$ of the sample $<0.5 \mathrm{~mm}$; particle size distribution data not shown), which resulted in higher washout fraction. The lower $K_{d}$ of the wDDGS may be mainly due to a large amount of slowly degradable NDF in the wDDGS and partly due to the production of Maillard products during the drying process of the wDDGS (Weiss et al., 1986). The higher $K_{d}$ of the wheat was mainly due to a large amount of rapidly degradable starch.

Wheat batch 3 was higher $(P<0.05)$ in the $\mathrm{D}$ fraction whereas batch 5 was higher in the $\mathrm{U}$ fraction. The EDDM was lower in batch $5(P<0.05)$ compared with batches 1 and 3 , and this pattern was reversed for RUDM (Table 5). The results of in situ degradation kinetics of wheat are in close agreement with the results published by Nuez-Ortín and Yu (2010), except those regarding the $\mathrm{S}$ fraction.

The method used to separate the 0 -h fraction, which was carried out according to Azarfar et al. (2007), was different from that used by Nuez-Ortín and Yu (2010), which might have contributed to the differences in the washout fraction (S). However, the higher washout fraction in this new type of mash co-product was also due to more small particles in the wDDGS.

Among the batches of wDDGS, we observed differences $(P<0.05)$ in $\mathrm{S}$ and $\mathrm{K}_{\mathrm{d}}$; however, $\mathrm{D}, \mathrm{U}, \mathrm{EDDM}$, and RUDM were similar. Nuez-Ortín and Yu (2009) indicated that the sources of wDDGS from different plants and the differences in particle size and texture of the co-products might influence the results of in situ studies, which may explain the present results, even though all samples came from the same bioethanol plant.

Compared with wDDGS, wheat was higher in D and $\mathrm{K}_{\mathrm{d}}$ values of OM. The wheat was higher in EDOM and lower in RUOM than the wDDGS. Among the wheat batches, we found significant differences $(P<0.05)$ in $\mathrm{D}, \mathrm{K}_{\mathrm{d}}, \mathrm{U}, \mathrm{EDOM}$, and RUOM. The ranges of EDOM and RUOM among the wheat batches were 88 and 85 $\mathrm{g} / \mathrm{kg}$ of DM, respectively. Other than the $\mathrm{K}_{\mathrm{d}}$ value, we found no significant differences in other rumen degradation parameters of OM among batches of wDDGS.

In Situ Rumen Degradation Characteristics of $\boldsymbol{C P}$. The wheat was higher $(P<0.05)$ in $\mathrm{D}$ of $\mathrm{CP}$ and lower in $\mathrm{S}$ of $\mathrm{CP}$ than the wDDGS (Table 5). The EDCP and RUP (g/kg of DM) of wheat were 3 times lower $(P<0.05)$ than that in the wDDGS. These results are in agreement with the fact that co-products are a rich source of RUP (Nuez-Ortín and Yu, 2010). The ranges in $\mathrm{D}, \mathrm{U}$, and $\mathrm{K}_{\mathrm{d}}$ among the wheat batches were $6.1,5.5$, and $11.5 \% / \mathrm{h}$, respectively. The EDCP was highest in the wheat batches 1 and 3 , and RUP was highest in batch 5 . The ranges of $\mathrm{S}$ and $\mathrm{D}$ among the batches of wDDGS were 5.9 and $7.4 \%$, respectively, with batch III having the highest D fraction, batches I and V having the highest EDCP, and batches I and III having the highest RUP fraction $(P<0.05)$.

In Situ Rumen Degradation Characteristics of NDF. Compared with wheat, wDDGS was higher in both EDNDF and RUNDF $(P<0.05$; Table 5$)$. Nuez-Ortín and Yu (2010) found that the NDF of coproducts is very digestible. This might be due to the presence of small particles to which microbes can easily attach; alternatively, the ethanol fermentation process might make the fiber more digestible.

Among the wheat batches, both EDNDF and RUNDF varied by $8 \mathrm{~g} / \mathrm{kg}$ of DM. Among the wDDGS, the S washable fraction varied by $5.9 \%$ of NDF and $K_{d}$ varied by $15 \% / \mathrm{h}$. The highest EDNDF value was obtained in wDDGS batch V. The results indicate that 30 to $36 \%$ of NDF from wDDGS was washed out from the nylon bags, indicating a fine particle size for the new type of co-product (mash-type), which differed dramatically from the type of wDDGS (marble-type) in the study by Nuez-Ortín and Yu (2010).

\section{Hourly Effective Degradation Ratios Between Nitrogen and Energy}

With the current high-yielding dairy cattle systems, it is necessary to maximize microbial protein yield. 
Table 4. Digestible nutrients (TDN) and energy values estimated using NRC (2001) and NRC (1996) models in different batches of feedstock for bioethanol production (wheat) and their co-products (wheat distillers dried grains with solubles, wDDGS) from the same bioethanol processing plant

\begin{tabular}{|c|c|c|c|c|c|c|c|c|c|c|c|c|c|c|c|}
\hline \multirow[b]{2}{*}{ Item } & \multirow[b]{2}{*}{$\begin{array}{l}\text { Wheat } \\
(\mathrm{n}=15)\end{array}$} & \multirow[b]{2}{*}{$\begin{array}{l}\text { wDDGS } \\
(\mathrm{n}=15)\end{array}$} & \multirow[b]{2}{*}{ SEM } & \multicolumn{5}{|c|}{ Wheat } & \multirow[b]{2}{*}{ SEM } & \multicolumn{5}{|c|}{ wDDGS } & \multirow[b]{2}{*}{ SEM } \\
\hline & & & & $\left(\begin{array}{c}1 \\
(\mathrm{n}=3)\end{array}\right.$ & $\left(\begin{array}{c}2 \\
(\mathrm{n}=3)\end{array}\right.$ & $\begin{array}{c}3 \\
(\mathrm{n}=3)\end{array}$ & $\begin{array}{c}4 \\
(\mathrm{n}=3)\end{array}$ & $\begin{array}{c}5 \\
(\mathrm{n}=3)\end{array}$ & & $(\mathrm{I}=3)$ & $\begin{array}{c}\mathrm{II} \\
(\mathrm{n}=3)\end{array}$ & $\begin{array}{c}\mathrm{III} \\
(\mathrm{n}=3)\end{array}$ & $\begin{array}{c}\mathrm{IV} \\
(\mathrm{n}=3)\end{array}$ & $\begin{array}{c}\mathrm{V} \\
(\mathrm{n}=3)\end{array}$ & \\
\hline \multicolumn{16}{|c|}{ Digestible nutrients $^{1}$ (\% of DM) } \\
\hline tdNFC & $72.40^{\mathrm{a}}$ & $24.26^{\mathrm{b}}$ & 0.401 & $71.29^{\mathrm{b}}$ & $72.18^{\mathrm{ab}}$ & $74.05^{\mathrm{a}}$ & $71.98^{\mathrm{b}}$ & $72.49^{\mathrm{ab}}$ & 0.367 & $22.71^{\mathrm{c}}$ & $25.46^{\mathrm{ab}}$ & $26.91^{\mathrm{a}}$ & $23.11^{\mathrm{bc}}$ & $23.11^{\text {bc }}$ & 0.589 \\
\hline $\mathrm{tdCP}$ & $14.25^{\mathrm{b}}$ & $42.18^{\mathrm{a}}$ & 0.300 & $15.09^{\mathrm{a}}$ & $14.36^{\mathrm{b}}$ & $12.96^{\mathrm{c}}$ & $14.50^{\mathrm{b}}$ & $14.34^{\mathrm{b}}$ & 0.087 & $44.30^{\mathrm{a}}$ & $43.00^{\mathrm{b}}$ & $41.50^{\mathrm{cd}}$ & $40.31^{\mathrm{c}}$ & $41.80^{\mathrm{bc}}$ & 0.263 \\
\hline tdFA & $0.43^{\mathrm{b}}$ & $4.13^{\mathrm{a}}$ & 0.047 & 0.21 & 0.40 & 0.55 & 0.52 & 0.48 & 0.112 & 4.16 & 4.08 & 4.18 & 4.24 & 3.98 & 0.084 \\
\hline tdNDF & $6.67^{\mathrm{b}}$ & $10.74^{\mathrm{a}}$ & 0.252 & $7.49^{\mathrm{a}}$ & $7.25^{\mathrm{a}}$ & $6.83^{\mathrm{a}}$ & $5.91^{\mathrm{b}}$ & $5.90^{\mathrm{b}}$ & 0.178 & $12.00^{\mathrm{a}}$ & $9.21^{\mathrm{c}}$ & $10.39^{\mathrm{bc}}$ & $11.78^{\mathrm{ab}}$ & $10.30^{\mathrm{bc}}$ & 0.589 \\
\hline $\mathrm{TDN}_{1 \times}{ }^{2}$ & $87.30^{\mathrm{a}}$ & $79.47^{\mathrm{b}}$ & 0.358 & $87.34^{\mathrm{abc}}$ & $87.70^{\mathrm{ab}}$ & $88.08^{\mathrm{a}}$ & $86.56^{\mathrm{c}}$ & $86.83^{\mathrm{bc}}$ & 0.191 & $81.37^{\mathrm{a}}$ & $79.86^{\mathrm{b}}$ & $81.23^{\mathrm{ab}}$ & $77.75^{\mathrm{c}}$ & $77.17^{\mathrm{c}}$ & 0.318 \\
\hline \multicolumn{16}{|c|}{ Predicted energy values ${ }^{3}$} \\
\hline $\mathrm{DE}_{3 \times}$ & $3.54^{\mathrm{b}}$ & $3.60^{\mathrm{a}}$ & 0.016 & $3.55^{\mathrm{ab}}$ & $3.56^{\mathrm{a}}$ & $3.56^{\mathrm{a}}$ & $3.52^{\mathrm{c}}$ & $3.53^{\mathrm{bc}}$ & 0.006 & $3.70^{\mathrm{a}}$ & $3.63^{\mathrm{b}}$ & $3.66^{\mathrm{ab}}$ & $3.51^{\mathrm{c}}$ & $3.50^{\mathrm{c}}$ & 0.013 \\
\hline $\mathrm{ME}_{3 \times}$ & $3.13^{\mathrm{b}}$ & $3.20^{\mathrm{a}}$ & 0.016 & $3.14^{\mathrm{a}}$ & $3.15^{\mathrm{a}}$ & $3.15^{\mathrm{a}}$ & $3.11^{\mathrm{b}}$ & $3.11^{\mathrm{ab}}$ & 0.008 & $3.30^{\mathrm{a}}$ & $3.22^{\mathrm{b}}$ & $3.25^{\mathrm{ab}}$ & $3.11^{\mathrm{c}}$ & $3.10^{\mathrm{c}}$ & 0.013 \\
\hline $\mathrm{NEL}_{3 \times}$ & $2.01^{\mathrm{b}}$ & $2.07^{\mathrm{a}}$ & 0.011 & $2.02^{\mathrm{ab}}$ & $2.02^{\mathrm{ab}}$ & $2.02^{\mathrm{ab}}$ & $1.99^{\mathrm{c}}$ & $2.00^{\mathrm{bc}}$ & 0.005 & $2.14^{\mathrm{a}}$ & $2.09^{\mathrm{b}}$ & $2.11^{\mathrm{ab}}$ & $2.01^{\mathrm{c}}$ & $2.00^{\mathrm{c}}$ & 0.010 \\
\hline $\mathrm{DE}_{4 \times}$ & $3.39^{\mathrm{b}}$ & $3.44^{\mathrm{a}}$ & 0.015 & $3.40^{\mathrm{a}}$ & $3.40^{\mathrm{a}}$ & $3.40^{\mathrm{a}}$ & $3.36^{\mathrm{b}}$ & $3.37^{\mathrm{b}}$ & 0.006 & $3.54^{\mathrm{a}}$ & $3.47^{\mathrm{b}}$ & $3.49^{\mathrm{ab}}$ & $3.35^{\mathrm{c}}$ & $3.35^{\mathrm{c}}$ & 0.013 \\
\hline $\mathrm{ME}_{4 \times}$ & $2.97^{\mathrm{b}}$ & $3.03^{\mathrm{a}}$ & 0.015 & $2.98^{\mathrm{ab}}$ & $2.99^{\mathrm{a}}$ & $2.99^{\mathrm{a}}$ & $2.95^{\mathrm{c}}$ & $2.96^{\mathrm{bc}}$ & 0.006 & $3.12^{\mathrm{a}}$ & $3.05^{\mathrm{b}}$ & $3.08^{\mathrm{ab}}$ & $2.94^{\mathrm{c}}$ & $2.93^{\mathrm{c}}$ & 0.013 \\
\hline $\mathrm{NE}_{\mathrm{L} 4 \times}$ & $1.90^{\mathrm{b}}$ & $1.95^{\mathrm{a}}$ & 0.011 & $1.91^{\mathrm{a}}$ & $1.91^{\mathrm{a}}$ & $1.91^{\mathrm{a}}$ & $1.88^{\mathrm{b}}$ & $1.89^{\mathrm{b}}$ & 0.004 & $2.02^{\mathrm{a}}$ & $1.97^{\mathrm{b}}$ & $1.99^{\mathrm{ab}}$ & $1.89^{\mathrm{c}}$ & $1.88^{\mathrm{c}}$ & 0.010 \\
\hline \multicolumn{16}{|c|}{ Predicted energy values ${ }^{4}$} \\
\hline $\mathrm{NE}_{\mathrm{M}}$ & $2.17^{\mathrm{b}}$ & $2.21^{\mathrm{a}}$ & 0.011 & $2.17^{\mathrm{ab}}$ & $2.18^{\mathrm{a}}$ & $2.18^{\mathrm{a}}$ & $2.15^{\mathrm{c}}$ & $2.15^{\mathrm{bc}}$ & 0.004 & $2.28^{\mathrm{a}}$ & $2.23^{\mathrm{b}}$ & $2.25^{\mathrm{ab}}$ & $2.14^{\mathrm{c}}$ & $2.14^{\mathrm{c}}$ & 0.010 \\
\hline $\mathrm{NE}_{\mathrm{G}}$ & $1.49^{\mathrm{b}}$ & $1.52^{\mathrm{a}}$ & 0.010 & $1.49^{\mathrm{ab}}$ & $1.50^{\mathrm{a}}$ & $1.50^{\mathrm{ab}}$ & $1.47^{\mathrm{c}}$ & $1.48^{\mathrm{bc}}$ & 0.004 & $1.58^{\mathrm{a}}$ & $1.54^{\mathrm{b}}$ & $1.56^{\mathrm{ab}}$ & $1.46^{\mathrm{c}}$ & $1.46^{\mathrm{c}}$ & 0.008 \\
\hline
\end{tabular}

${ }^{\mathrm{a}-\mathrm{c}}$ Means with different superscripts letters in the same row are significantly different $(P<0.05)$

${ }^{1}$ tdNFC $=$ digestible NFC; tdCP $=$ digestible $\mathrm{CP} ; \mathrm{tdNDF}=$ digestible NDF; tdFA $=$ digestible FA.

${ }^{2}$ Total digestible nutrients at maintenance estimated from NRC (2001) dairy model (\% of DM).

${ }^{3} \mathrm{DE}_{3 \times}, \mathrm{ME}_{3 \times}, \mathrm{NEL}_{3 \times}, \mathrm{DE}_{4 \times}, \mathrm{ME}_{4 \times}$, and $\mathrm{NEL}_{4 \times}=$ digestible energy, $\mathrm{ME}$, and $\mathrm{NE}_{\mathrm{L}}$, respectively, at 3 times and 4 times maintenance estimated from the $\mathrm{NRC}$ (2001) dairy model (Mcal/kg of DM).

${ }^{4} \mathrm{NE}_{\mathrm{M}}$ and $\mathrm{NE}_{\mathrm{G}}$ estimated from the NRC (1996) beef model (Mcal/kg of DM). 
Provision of feed with optimal ratio between effective degradability of $\mathrm{N}$ and $\mathrm{OM}$ is one way of achieving maximum microbial yield and synchronizing $\mathrm{N}$ and energy utilization. According to the literature, $25 \mathrm{~g}$ of $\mathrm{N}$ per $\mathrm{kg}$ of $\mathrm{OM}$ truly degraded in the rumen will maximize microbial protein synthesis (Czerkawski, 1986; Tamminga et al., 1990, 1994; Sinclair et al., 1993). Higher ratios indicate potential $\mathrm{N}$ loss or shortage of available energy for microbial growth, and lower ratios indicate inadequacy of $\mathrm{N}$ or excess available energy for microbial growth. In both cases, the effect on the animal or the environment is negative. Moreover, for the economic viability of production systems, the measurement of effective degradation ratios between $\mathrm{N}$ and $\mathrm{OM}$ in ingredients is a useful tool for ration formulation. The hourly ratios of EDN to EDOM were lower $(P$ $<0.05)$ in the wheat compared with wDDGS at all incubation time points (Table 5). The EDN to EDOM ratios of wheat batches ranged from 13 to 57, whereas those in wDDGS batches ranged from 64 to $88 \mathrm{~g}$ of N/ $\mathrm{kg}$ of $\mathrm{OM}$ at 0 to $12 \mathrm{~h}$.

Among the wheat batches, we observed significant differences $(P<0.05)$ in the ratio of EDN to EDOM at $6 \mathrm{~h}$ of incubation, which varied from 19 to $25 \mathrm{~g}$ of N/ $\mathrm{kg}$ of OM. We also found significant differences $(P<0.05)$ among batches of wDDGS at 0,6 , and $12 \mathrm{~h}$ of incubation with ratios of EDN to EDOM of 24, 9, and $16 \mathrm{~g}$ of $\mathrm{N} / \mathrm{kg}$ of OM, respectively. The ratios of all wDDGS were much higher than the optimum of $25 \mathrm{~g}$ of N/kg of OM (Czerkawski, 1986; Tamminga et al., 1990, 1994).

These results suggest a potential loss of $\mathrm{N}$ or limitation of energy supply that will cause higher ratios of EDN to EDOM when the wDDGS is evaluated as a single feed ingredient (feed up to $60 \%$ of co-products reported by Gibb et al., 2008).

\section{Intestinal Digestibility of RUP}

For modern high-yielding dairy cow feeding systems, it is necessary to predict the availability of protein not only for rumen microbial synthesis but also for digestion in the small intestine. Evidence exists of a negative correlation between increased milk yield and decreased rumen degradation of $\mathrm{CP}$ from various sources if the diet has sufficient ruminal available N (Ørskov et al., 1980; Netemeyer et al., 1982; Sahlu et al., 1984). The feedstock of wheat was higher in the intestinal digestibility of rumen undegraded feed protein $(P<0.05)$ than wDDGS (\% dRUP: 79 vs. $67 \%$; Table 6 ). Among the wheat batches, intestinal digestibility of RUP varied by $7.3 \%$, whereas that in wDDGS varied by $6.8 \%$. For wheat, the highest digestibility of RUP was found in batch $1(83.3 \%)$, whereas for wDDGS, the highest digestibility of RUP was found in batch III (71\%), which disagrees with the $85 \%$ assumed in NRC (1996) for RUP from any feed sources. This result indicated that bioethanol processing reduced intestinal digestibility of RUP by $12 \%$, and the variation of intestinal digestibility of RUP between the batches in wheat and wDDGS was around $7 \%$.

\section{Metabolic Characteristics of Protein and Predicted Truly Absorbed Protein Supply with the DVE/OEB System Affected by Batch}

Metabolic characteristics of proteins in dairy cattle in different batches of wheat for bioethanol production and wDDGS from the same bioethanol processing plant were calculated with the DVE/OEB system according to Tamminga et al. (1994; Table 6)

Microbial Protein Synthesis and Truly Absorbed Microbial Protein in Small Intestine. In the DVE/OEB system, microbial protein synthesis is based on fermentable OM. Because the wheat was higher in starch and DOM and lower in CFat and RUP than the wDDGS, MCP $\mathrm{FOM}$ and AMCP values were also higher in the wheat (Table 6). Among the wheat batches, the ranges of $\mathrm{MCP}_{\mathrm{FOM}}$ and $\mathrm{AMCP}$ were 15 and $10 \mathrm{~g} / \mathrm{kg}$ of DM, respectively, but were much smaller in the wDDGS batches ( 4 and $3 \mathrm{~g} / \mathrm{kg}$ of DM). The microbial protein synthesized based on energy released during anaerobic fermentation process $\left(\mathrm{MCP}_{\mathrm{FOM}}\right)$ was lower than the MCP synthesized based on RDP for the wDDGS, and the average values obtained were 105 and $272 \mathrm{~g} / \mathrm{kg} \mathrm{DM}$ for $\mathrm{MCP}_{\mathrm{FOM}}$ and $\mathrm{MCP}_{\mathrm{RDP}}$, respectively. The $\mathrm{MCP}_{\mathrm{RDP}}$ varied among the wheat batches by 16.0 $\mathrm{g} / \mathrm{kg}$ of DM and among the wDDGS batches, the range for $\mathrm{MCP}_{\mathrm{RDP}}$ was $38 \mathrm{~g} / \mathrm{kg}$ of DM.

Truly Absorbed Rumen Undegraded Feed Protein in Small Intestine. The RUP content was higher in the wDDGS than in the wheat. As a result, ARUP was greater in the wDDGS as well (106 vs. 41 $\mathrm{g} / \mathrm{kg}$ of DM, respectively; Table 6 ), indicating that the co-product is a good source of dietary bypassed protein. The RUP content varied among the wheat batches by $27 \mathrm{~g} / \mathrm{kg}$ of DM and among the wDDGS batches by $32 \mathrm{~g} / \mathrm{kg}$ of DM. Even though we found significant differences $(P<0.05)$ between the wheat and wDDGS in the predicted endogenous protein losses, we found no significant difference among the wheat batches and among the wDDGS batches.

Total DVE and OEB. The wDDGS was much higher in total truly absorbed protein supply, with DVE values of 169 and $109 \mathrm{~g} / \mathrm{kg}$ of DM for wDDGS and 
Table 5. Average particle size, in situ rumen degradation kinetics of DM, OM, CP, and NDF, and hourly effective degradation ratio of $\mathrm{N}$ to energy (OM) to show potential N to energy synchronization in different batches of feedstock for bioethanol production (wheat) and their co-products (wheat distillers dried grains with solubles, wDDGS) from the same bioethanol processing plant

\begin{tabular}{|c|c|c|c|c|c|c|c|c|c|c|c|}
\hline \multirow[b]{2}{*}{ Item $^{1}$} & \multirow[b]{2}{*}{$\begin{array}{l}\text { Wheat } \\
(\mathrm{n}=6)\end{array}$} & \multirow[b]{2}{*}{$\begin{array}{c}\text { wDDGS } \\
(\mathrm{n}=6)\end{array}$} & \multirow[b]{2}{*}{ SEM } & \multicolumn{3}{|c|}{ Wheat } & \multirow[b]{2}{*}{ SEM } & \multicolumn{3}{|c|}{ wDDGS } & \multirow[b]{2}{*}{ SEM } \\
\hline & & & & $\left(\begin{array}{c}1 \\
=2\end{array}\right)$ & $\left(\begin{array}{c}3 \\
(\mathrm{n}=3)\end{array}\right.$ & $\begin{array}{c}5 \\
(\mathrm{n}=3)\end{array}$ & & $\left(\begin{array}{c}\mathrm{I} \\
(\mathrm{n}=3)\end{array}\right.$ & $\begin{array}{c}\text { III } \\
(\mathrm{n}=3)\end{array}$ & $\begin{array}{c}\mathrm{V} \\
(\mathrm{n}=3)\end{array}$ & \\
\hline Geometric mean particle size $(\mu \mathrm{m})$ & $1,695.3^{\mathrm{a}}$ & $674.4^{\mathrm{b}}$ & 16.43 & $1,628.5$ & $1,701.8$ & $1,755.7$ & 34.76 & $649.8^{\mathrm{b}}$ & $683.0^{\mathrm{a}}$ & $690.3^{\mathrm{a}}$ & 6.64 \\
\hline \multicolumn{12}{|l|}{ Particle size distribution (\%) } \\
\hline Sieve \#6 (3.36 mm) & $5.2^{\mathrm{a}}$ & $0.1^{\mathrm{b}}$ & 0.23 & $6.2^{\mathrm{a}}$ & $4.1^{\mathrm{b}}$ & $5.2^{\mathrm{ab}}$ & 0.45 & 0.1 & 0.1 & 0.0 & 0.03 \\
\hline Sieve \#8 (2.38 mm) & $25.6^{\mathrm{a}}$ & $0.1^{\mathrm{b}}$ & 0.48 & 24.3 & 25.8 & 26.7 & 1.18 & $0.1^{\mathrm{a}}$ & $0.1^{\mathrm{ab}}$ & $0.0^{\mathrm{b}}$ & 0.02 \\
\hline Sieve \#12 $(1.68 \mathrm{~mm})$ & $31.3^{\mathrm{a}}$ & $0.4^{\mathrm{b}}$ & 0.47 & $27.9^{\mathrm{b}}$ & $32.9^{\mathrm{a}}$ & $33.2^{\mathrm{a}}$ & 0.60 & 0.3 & 0.4 & 0.3 & 0.02 \\
\hline Sieve \#16 (1.19 mm) & $16.2^{\mathrm{a}}$ & $5.4^{\mathrm{b}}$ & 0.36 & 15.6 & 16.9 & 16.0 & 0.73 & $4.4^{\mathrm{b}}$ & $6.5^{\mathrm{a}}$ & $5.3^{\mathrm{ab}}$ & 0.36 \\
\hline Sieve \#20 (0.84 mm) & $5.1^{\mathrm{b}}$ & $17.0^{\mathrm{a}}$ & 0.38 & 5.1 & 5.0 & 5.1 & 0.19 & $14.6^{\mathrm{b}}$ & $18.0^{\mathrm{a}}$ & $18.4^{\mathrm{a}}$ & 0.59 \\
\hline Sieve \#30 (0.59 mm) & $4.5^{\mathrm{b}}$ & $34.2^{\mathrm{a}}$ & 0.62 & 4.6 & 4.6 & 4.2 & 0.26 & $31.3^{\mathrm{b}}$ & $32.4^{\mathrm{b}}$ & $38.8^{\mathrm{a}}$ & 0.59 \\
\hline Bottom pan $(<0.59 \mathrm{~mm})$ & $10.9^{\mathrm{b}}$ & $42.7^{\mathrm{a}}$ & 1.16 & $13.8^{\mathrm{a}}$ & $10.0^{\mathrm{b}}$ & $9.02^{\mathrm{b}}$ & 0.95 & $49.0^{\mathrm{a}}$ & $42.3^{\mathrm{b}}$ & $36.6^{\mathrm{c}}$ & 1.53 \\
\hline \multicolumn{12}{|c|}{ In situ rumen degradation kinetics of DM } \\
\hline $\mathrm{S}(\%)$ & $7.3^{\mathrm{b}}$ & $35.0^{\mathrm{a}}$ & 2.00 & 8.0 & 6.9 & 7.0 & 2.09 & $33.8^{\mathrm{b}}$ & $36.2^{\mathrm{a}}$ & $34.9^{\mathrm{ab}}$ & 1.93 \\
\hline $\mathrm{D}(\%)$ & $81.7^{\mathrm{a}}$ & $49.6^{\mathrm{b}}$ & 2.21 & $81.3^{\mathrm{ab}}$ & $83.5^{\mathrm{a}}$ & $80.3^{\mathrm{b}}$ & 2.66 & 50.7 & 49.2 & 48.8 & 1.84 \\
\hline $\mathrm{K}_{\mathrm{d}}(\% / \mathrm{h})$ & $25.3^{\mathrm{a}}$ & $10.6^{\mathrm{b}}$ & 1.45 & $25.9^{\mathrm{ab}}$ & $31.0^{\mathrm{a}}$ & $18.9^{\mathrm{b}}$ & 2.22 & $10.2^{\mathrm{ab}}$ & $8.9^{\mathrm{b}}$ & $12.7^{\mathrm{a}}$ & 1.79 \\
\hline $\mathrm{U}(\%)$ & $11.0^{\mathrm{b}}$ & $15.5^{\mathrm{a}}$ & 0.42 & $10.7^{\mathrm{b}}$ & $9.6^{\mathrm{b}}$ & $12.7^{\mathrm{a}}$ & 0.67 & 15.6 & 14.6 & 16.2 & 0.49 \\
\hline EDDM $(\%)$ & $72.7^{\mathrm{a}}$ & $66.2^{\mathrm{b}}$ & 0.96 & $73.9^{\mathrm{a}}$ & $76.5^{\mathrm{a}}$ & $67.7^{\mathrm{b}}$ & 1.03 & 65.6 & 65.5 & 67.5 & 1.12 \\
\hline RUDM $(\%)$ & $27.3^{\mathrm{b}}$ & $33.8^{\mathrm{a}}$ & 0.96 & $26.1^{\mathrm{b}}$ & $23.5^{\mathrm{b}}$ & $32.4^{\mathrm{a}}$ & 1.03 & 34.4 & 34.5 & 32.5 & 1.12 \\
\hline \multicolumn{12}{|c|}{ In situ rumen degradation kinetics of $\mathrm{OM}$} \\
\hline $\mathrm{S}(\%)$ & $6.9^{\mathrm{b}}$ & $32.4^{\mathrm{a}}$ & 2.08 & 7.7 & 6.4 & 6.5 & 2.21 & $31.3^{\mathrm{b}}$ & $33.6^{\mathrm{a}}$ & $32.2^{\mathrm{ab}}$ & 1.99 \\
\hline $\mathrm{D}(\%)$ & $82.1^{\mathrm{a}}$ & $51.9^{\mathrm{b}}$ & 2.29 & $81.6^{\mathrm{ab}}$ & $84.0^{\mathrm{a}}$ & $80.8^{\mathrm{b}}$ & 2.78 & 52.9 & 51.5 & 51.2 & 1.90 \\
\hline $\mathrm{K}_{\mathrm{d}}(\% / \mathrm{h})$ & $25.6^{\mathrm{a}}$ & $10.5^{\mathrm{b}}$ & 1.47 & $26.3^{\mathrm{ab}}$ & $31.3^{\mathrm{a}}$ & $19.2^{\mathrm{b}}$ & 2.31 & $10.2^{\mathrm{ab}}$ & $8.9^{\mathrm{b}}$ & $12.6^{\mathrm{a}}$ & 1.75 \\
\hline $\mathrm{U}(\%)$ & $11.0^{\mathrm{b}}$ & $15.8^{\mathrm{a}}$ & 0.43 & $10.8^{\mathrm{ab}}$ & $9.6^{\mathrm{b}}$ & $12.7^{\mathrm{a}}$ & 0.68 & 15.8 & 14.9 & 16.6 & 0.51 \\
\hline EDOM $(\%)$ & $72.8^{\mathrm{a}}$ & $65.0^{\mathrm{b}}$ & 0.96 & $74.0^{\mathrm{a}}$ & $76.6^{\mathrm{a}}$ & $67.8^{\mathrm{b}}$ & 1.05 & 64.4 & 64.2 & 66.3 & 1.16 \\
\hline EDOM $(\mathrm{g} / \mathrm{kg}$ of $\mathrm{DM})$ & $714^{\mathrm{a}}$ & $615^{\mathrm{b}}$ & 9.5 & $726^{\mathrm{a}}$ & $752^{\mathrm{a}}$ & $664^{\mathrm{b}}$ & 10.4 & 610 & 608 & 626 & 11.0 \\
\hline RUOM $(\%)$ & $27.2^{\mathrm{b}}$ & $35.0^{\mathrm{a}}$ & 0.96 & $26.0^{\mathrm{b}}$ & $23.5^{\mathrm{b}}$ & $32.2^{\mathrm{a}}$ & 1.05 & 35.6 & 35.8 & 33.7 & 1.16 \\
\hline RUOM (g/kg of DM) & $267^{\mathrm{b}}$ & $331^{\mathrm{a}}$ & 9.3 & $255^{\mathrm{b}}$ & $230^{\mathrm{b}}$ & $315^{\mathrm{a}}$ & 10.2 & 337 & 339 & 317 & 10.9 \\
\hline \multicolumn{12}{|c|}{ In situ rumen degradation kinetics of $\mathrm{CP}$} \\
\hline $\mathrm{S}(\%)$ & $12.7^{\mathrm{b}}$ & $34.3^{\mathrm{a}}$ & 7.55 & 12.9 & 11.7 & 13.5 & 10.53 & $36.2^{\mathrm{a}}$ & $30.4^{\mathrm{b}}$ & $36.3^{\mathrm{a}}$ & 4.54 \\
\hline $\mathrm{D}(\%)$ & $79.8^{\mathrm{a}}$ & $54.6^{\mathrm{b}}$ & 6.77 & $82.1^{\mathrm{a}}$ & $81.3^{\mathrm{a}}$ & $76.0^{\mathrm{b}}$ & 10.02 & $53.1^{\mathrm{b}}$ & $59.1^{\mathrm{a}}$ & $51.7^{\mathrm{b}}$ & 3.50 \\
\hline $\mathrm{K}_{\mathrm{d}}(\% / \mathrm{h})$ & 14.2 & 9.8 & 2.23 & $12.5^{\mathrm{ab}}$ & $20.8^{\mathrm{a}}$ & $9.3^{\mathrm{b}}$ & 2.19 & 8.3 & 7.9 & 13.3 & 3.25 \\
\hline $\mathrm{U}(\%)$ & $7.5^{\mathrm{b}}$ & $11.0^{\mathrm{a}}$ & 0.94 & $5.0^{\mathrm{b}}$ & $7.0^{\mathrm{b}}$ & $10.5^{\mathrm{a}}$ & 0.68 & 10.7 & 10.5 & 12.0 & 1.39 \\
\hline $\operatorname{EDCP}(\%)$ & $67.3^{\mathrm{a}}$ & $66.8^{\mathrm{b}}$ & 4.33 & $68.2^{\mathrm{a}}$ & $74.0^{\mathrm{a}}$ & $59.6^{\mathrm{b}}$ & 2.06 & $66.9^{\mathrm{ab}}$ & $63.3^{\mathrm{b}}$ & $70.4^{\mathrm{a}}$ & 1.53 \\
\hline $\operatorname{EDCP}(\mathrm{g} / \mathrm{kg}$ of $\mathrm{DM})$ & $95.0^{\mathrm{a}}$ & $287.4^{\mathrm{b}}$ & 4.33 & $102.8^{\mathrm{a}}$ & $95.8^{\mathrm{a}}$ & $86.5^{\mathrm{b}}$ & 2.9 & $301^{\mathrm{a}}$ & $264^{\mathrm{b}}$ & $296^{\mathrm{a}}$ & 6.6 \\
\hline RUP (\%) & 32.8 & 33.2 & 1.60 & $31.8^{\mathrm{b}}$ & $26.1^{\mathrm{b}}$ & $40.4^{\mathrm{a}}$ & 2.06 & $33.1^{\mathrm{ab}}$ & $36.7^{\mathrm{a}}$ & $29.6^{\mathrm{b}}$ & 1.53 \\
\hline RUP $(\mathrm{g} / \mathrm{kg}$ of DM) & $52^{\mathrm{b}}$ & $151^{\mathrm{a}}$ & 4.5 & $53^{\mathrm{b}}$ & $38^{\mathrm{c}}$ & $65^{\mathrm{a}}$ & 3.1 & $166^{\mathrm{a}}$ & $170^{\mathrm{a}}$ & $139^{\mathrm{b}}$ & 7.2 \\
\hline \multicolumn{12}{|c|}{ In situ rumen degradation kinetics of NDF } \\
\hline $\mathrm{S}(\%)$ & $12.7^{\mathrm{b}}$ & $34.3^{\mathrm{a}}$ & 7.55 & 12.9 & 11.7 & 13.5 & 10.53 & $36.2^{\mathrm{a}}$ & $30.4^{\mathrm{b}}$ & $36.3^{\mathrm{a}}$ & 4.54 \\
\hline $\mathrm{D}(\%)$ & $50.4^{\mathrm{a}}$ & $70.2^{\mathrm{a}}$ & 1.00 & 52.7 & 51.7 & 46.8 & 2.07 & 70.4 & 69.6 & 70.6 & 0.85 \\
\hline $\mathrm{K}_{\mathrm{d}}(\% / \mathrm{h})$ & $19.3^{\mathrm{b}}$ & $32.0^{\mathrm{a}}$ & 3.50 & 12.4 & 21.3 & 24.3 & 7.60 & $23.2^{\mathrm{b}}$ & $34.9^{\mathrm{ab}}$ & $37.7^{\mathrm{a}}$ & 3.28 \\
\hline $\mathrm{U}(\%)$ & $47.7^{\mathrm{a}}$ & $29.8^{\mathrm{b}}$ & 1.65 & $43.5^{\mathrm{b}}$ & $46.4^{\mathrm{ab}}$ & $53.2^{\mathrm{a}}$ & 3.34 & 29.7 & 30.4 & 29.4 & 0.85 \\
\hline EDNDF (\%) & $37.4^{\mathrm{b}}$ & $58.4^{\mathrm{a}}$ & 1.07 & $37.6^{\mathrm{ab}}$ & $40.8^{\mathrm{a}}$ & $33.8^{\mathrm{a}}$ & 1.61 & $55.1^{\mathrm{b}}$ & $59.2^{\mathrm{ab}}$ & $60.9^{\mathrm{a}}$ & 1.04 \\
\hline EDNDF $(\mathrm{g} / \mathrm{kg}$ of DM $)$ & $42.0^{\mathrm{b}}$ & $132.3^{\mathrm{a}}$ & 2.68 & $44.0^{\mathrm{ab}}$ & $45.1^{\mathrm{a}}$ & $36.9^{\mathrm{b}}$ & 2.05 & $122.6^{\mathrm{b}}$ & $128.3^{\mathrm{b}}$ & $146.0^{\mathrm{a}}$ & 3.31 \\
\hline RUNDF $(\%)$ & $62.6^{\mathrm{a}}$ & $41.6^{\mathrm{b}}$ & 1.07 & $62.5^{\mathrm{ab}}$ & $59.8^{\mathrm{b}}$ & $66.2^{\mathrm{a}}$ & 1.61 & $44.9^{\mathrm{a}}$ & $40.8^{\mathrm{ab}}$ & $39.2^{\mathrm{b}}$ & 1.04 \\
\hline RUNDF (g/kg of DM) & $70.2^{\mathrm{b}}$ & $94.0^{\mathrm{a}}$ & 1.65 & $73.2^{\mathrm{a}}$ & $65.2^{\mathrm{b}}$ & $72.2^{\mathrm{a}}$ & 1.57 & $100.0^{\mathrm{a}}$ & $88.1^{\mathrm{b}}$ & $93.9^{\mathrm{ab}}$ & 3.28 \\
\hline
\end{tabular}


wheat, respectively, and degraded protein balance, with OEB values of 167 and $-23 \mathrm{~g} / \mathrm{kg}$ of DM for wDDGS and wheat, respectively (Table 6). The range of DVE values was $15 \mathrm{~g} / \mathrm{kg}$ of $\mathrm{DM}$ among the wheat batches and $29 \mathrm{~g} / \mathrm{kg}$ of DM among the wDDGS batches. For wheat batches, the OEB value was negative, which indicates the potential shortage of $\mathrm{N}$ for microbial protein synthesis. The negative OEB value is due to fact that the microbial protein synthesized based on energy released during anaerobic fermentation process $\left(\mathrm{MCP}_{\mathrm{FOM}}\right)$ was higher than the MCP synthesized based on RDP for the wheat. The results obtained for OEB values in wheat were not in agreement with the values obtained by Nuez-Ortín and $\mathrm{Yu}$ (2010), in which the OEB value for wheat was positive $(107 \mathrm{~g} / \mathrm{kg}$ of $\mathrm{DM})$. The values obtained for DVE are in agreement with the values obtained by Nuez-Ortín and Yu (2010). The results show that the wDDGS contained higher truly absorbable proteins of DVE, which could be used to replace expensive protein meal in animal diets.

\section{Molecular Spectral Profiles in Different Batches of Wheat and wDDGS}

The typical FTIR molecular spectrum of the feedstock of wheat and wDDGS from bioethanol processing in the whole mid-IR region $\left(\sim 4,000-800 \mathrm{~cm}^{-1}\right)$ is shown in Figure 1. The whole spectrum contains unique absorption peaks at different wave numbers, which are associated with unique biomolecular chemical structure profile in the wheat and wDDGS. Figure 1 highlights different spectral regions (windows) that are associated with different chemical functional groups or biomolecules in the wheat and wDDGS. To determine chemical structure differences on a molecular basis in the fingerprint region $\left(\sim 1,800-800 \mathrm{~cm}^{-1}\right)$ in the wheat and wDDGS from the same bioethanol processing plant, we applied 2 multivariate molecular analysis techniques (AHCA and PCA). Molecular spectral differences are related to molecular structure makeup. The most important mid-IR region is the fingerprint region, which contains important functional groups and biomolecules that are related to feed quality and nutrient availability.

Figure 2 shows the molecular spectral comparison between wheat and wDDGS in the fingerprint region. Both the AHCA and PCA analyses showed molecular spectral differences between wheat and wDDGS. The dendrogram of AHCA analysis showed 2 distinct groups at a linkage distance $\sim 2$ for wheat and wDDGS. Similar results were observed with scattered plot of PCA, in which 2 clearly demarcated ellipses represent wheat and wDDGS. The PC1 and PC2 explain 83.3 and $15.6 \%$ of variation of spectral data, respectively. This supports the results obtained with chemical analysis and nutri- 
Table 6. Metabolic characteristics of proteins and estimated intestinal digestibility of rumen undegraded feed protein in feedstock for bioethanol production (wheat) and its coproduct (wheat distillers dried grains with solubles, wDDGS) from bioethanol processing

\begin{tabular}{|c|}
\hline Item $^{1}$ \\
\hline
\end{tabular}

Truly absorbed rumen undegraded feed protein in the small intestine $(\mathrm{g} / \mathrm{kg}$ of $\mathrm{DM})$

RUP

Truly absorbed rumen synthesized microbial protein and total true protein supplied to the small intestine $(\mathrm{g} / \mathrm{kg}$ of $\mathrm{DM})$

FOM

$\mathrm{MCP}_{\mathrm{FOM}}$

EDCP

$\mathrm{MCP}_{\mathrm{RDP}}$

AMCP

TPSI

$\begin{array}{rrrrrrrrrrr}52^{\mathrm{b}} & 158^{\mathrm{a}} & 4.5 & 53^{\mathrm{b}} & 38^{\mathrm{c}} & 65^{\mathrm{a}} & 3.1 & 166^{\mathrm{a}} & 170^{\mathrm{a}} & 139^{\mathrm{b}} & 7.2 \\ 41^{\mathrm{b}} & 106^{\mathrm{a}} & 4.7 & 44^{\mathrm{a}} & 29^{\mathrm{b}} & 50^{\mathrm{a}} & 1.8 & 109^{\mathrm{a}} & 121^{\mathrm{a}} & 89^{\mathrm{b}} & 7.8\end{array}$

Endogenous protein loss in the digestive tract $(\mathrm{g} / \mathrm{kg}$ of $\mathrm{DM})$ UDM

ENDP

$\begin{array}{rrrrrrrrrrr}751^{\mathrm{a}} & 698^{\mathrm{b}} & 11.3 & 778^{\mathrm{a}} & 788^{\mathrm{a}} & 686^{\mathrm{b}} & 11.7 & 691^{\mathrm{b}} & 685^{\mathrm{b}} & 717^{\mathrm{a}} & 6.9 \\ 113^{\mathrm{a}} & 105^{\mathrm{b}} & 1.70 & 117^{\mathrm{a}} & 118^{\mathrm{a}} & 101^{\mathrm{b}} & 1.8 & 104^{\mathrm{b}} & 103^{\mathrm{b}} & 108^{\mathrm{a}} & 1.0 \\ 95^{\mathrm{b}} & 287^{\mathrm{a}} & 4.3 & 103^{\mathrm{a}} & 96^{\mathrm{a}} & 87^{\mathrm{b}} & 2.9 & 301^{\mathrm{a}} & 264^{\mathrm{b}} & 296^{\mathrm{a}} & 6.6 \\ 90^{\mathrm{b}} & 272^{\mathrm{a}} & 4.6 & 98^{\mathrm{a}} & 92^{\mathrm{a}} & 80^{\mathrm{b}} & 3.2 & 285^{\mathrm{a}} & 247^{\mathrm{b}} & 283^{\mathrm{a}} & 7.3 \\ 72^{\mathrm{a}} & 67^{\mathrm{b}} & 1.1 & 74^{\mathrm{a}} & 75^{\mathrm{a}} & 66^{\mathrm{b}} & 1.12 & 66^{\mathrm{b}} & 66^{\mathrm{b}} & 68.6^{\mathrm{a}} & 0.7 \\ 136^{\mathrm{b}} & 237^{\mathrm{a}} & 3.7 & 141^{\mathrm{a}} & 126^{\mathrm{b}} & 142^{\mathrm{a}} & 3.1 & 243^{\mathrm{a}} & 247^{\mathrm{a}} & 219^{\mathrm{b}} & 6.5\end{array}$

DVE $(\mathrm{g} / \mathrm{kg}$ of DM)

$\begin{array}{crrrrrrrrrr}39 & 39 & 1.8 & 32 & 39 & 45 & 3.5 & 39 & 38 & 39 & 1.5 \\ 3^{\mathrm{b}} & 4^{\mathrm{a}} & 0.1 & 3 & 3 & 4 & 0.26 & 4 & 4 & 4 & 0.1\end{array}$

Protein degraded balance $(\mathrm{OEB}, \mathrm{g} / \mathrm{kg}$ of $\mathrm{DM})$

$109^{\mathrm{b}} \quad 169^{\mathrm{b}}$

${ }^{\mathrm{a}, \mathrm{b}}$ Means with different superscripts letters in the same row are significantly different $(P<0.05)$.

${ }^{1} \mathrm{ARUP}=$ rumen undegraded feed protein truly absorbed in small intestine; $\mathrm{FOM}=\mathrm{OM}$ fermented in the rumen, $\mathrm{MCP}_{\mathrm{FOM}}=$ microbial protein synthesized from rumen available energy based on DVE system; EDCP = effectively degraded feed protein in the rumen; $\mathrm{MCP}_{\mathrm{RDP}}=$ microbial protein synthesized in the rumen based on rumen degraded feed protein; AMCP = truly absorbed rumen synthesized microbial protein in the small intestine; TPSI $=$ true protein supplied to the small intestine; UDM = undigested DM; ENDP $=$ endogenous protein losses in the digestive tract; $\mathrm{DVE}=$ truly absorbed protein in the small intestine supplied by $\mathrm{RUP}, \mathrm{MCP}_{\mathrm{FOM}}$, and correction for ENDP; OEB = difference between potential microbial protein synthesis based on rumen degraded feed protein and that based on energy available for microbial fermentation in the rumen. 

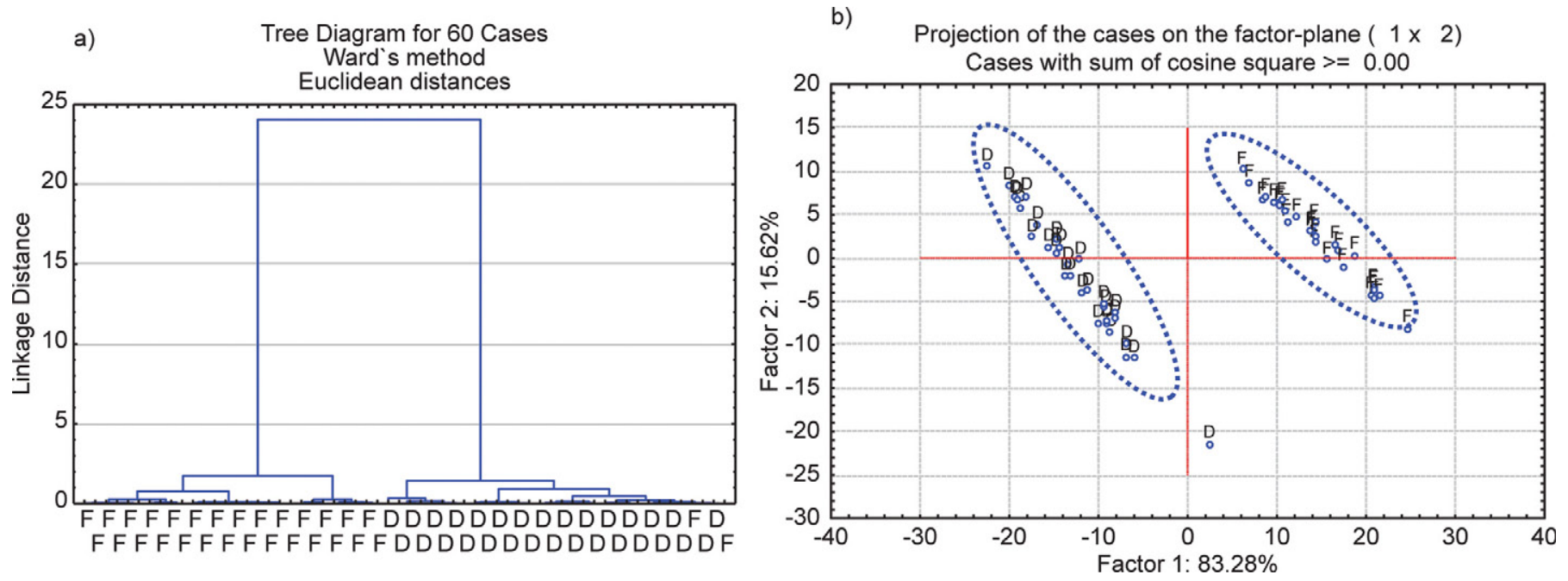

Figure 2. Multivariate molecular spectral analyses in fingerprint region $\left(\sim 1,800-800 \mathrm{~cm}^{-1}\right)$ : Comparison of the feedstock (wheat, F) for bioethanol production with co-product from bioethanol processing (wheat distillers dried grains with solubles, wDDGS, D). (a) Cluster analysis with Euclidean distance and Ward's algorithm cluster methods: cluster analysis (AHCA) in fingerprint region $\sim 1,800-800 \mathrm{~cm}^{-1}$ and $(\mathrm{b})$ principal component analysis in fingerprint region $\sim 1,800-800 \mathrm{~cm}^{-1}$ showing a molecular spectral comparison of wheat versus wDDGS. Principal components (PC) 1 and 2 explain 83.28 and $15.62 \%$ of the variation of spectral data, respectively. Color version available in the online PDF.

ent availability studies that significant differences were observed between wheat and wDDGS.

The molecular spectral comparison between the wheat batches is shown in Figure 3. The spectral differences between wheat batch 1 versus 3 , batch 1 versus 5 , and batch 3 versus 5 were analyzed by AHCA and PCA. The results showed some overlap between batches 1 and 3 and batches 1 and 5, both in dendrograms and scattered plots of PCA, indicating similar intrinsic structural characteristics of wheat batches in batch 1 compared with batches 3 and 5 . Wheat batches 3 and 5 formed 2 different groups below the linkage distance 0.01 in AHCA, and PCA showed 2 clearly distinguishable ellipses in which PC1 and PC2 explained 94.80\% and $5.06 \%$ of variation of spectral data, respectively. The molecular spectral comparison between wDDGS is shown in Figure 4: wDDGS batch I versus III, batch I versus $\mathrm{V}$, and batch III versus $\mathrm{V}$ showed some overlap in dendrograms of AHCA and scattered plots of PCA. These results indicate the molecular spectral difference among the batches of wheat and wDDGS. Further study is needed to analyze molecular functional group intensity in relation to nutrient availability in this type of co-product using univariate molecular spectral analysis.

\section{CONCLUSIONS}

Protein metabolic characteristics and degraded protein balance in the feedstock of wheat for bioethanol production and their co-products (wDDGS) from the same bioethanol processing plant were affected by batch. Total truly absorbed protein supply (DVE value) ranged from 101 to $116 \mathrm{~g} / \mathrm{kg}$ of $\mathrm{DM}$ in the wheat batches and from 153 to $182 \mathrm{~g} / \mathrm{kg}$ of $\mathrm{DM}$ in wDDGS. The degraded protein balance (OEB value) in the wDDGS was affected by wDDGS batch, with OEB values ranging from 145 to $181 \mathrm{~g} / \mathrm{kg}$ of DM. Wheat had a negative degraded protein balance, with values ranging from -19 to $-26 \mathrm{~g} / \mathrm{kg}$ of DM. Different batches of wDDGS had different protein metabolic characteristics, even though they were from the same bioethanol processing plant. The AHCA and PCA methods revealed biomolecular spectral profiles among the feedstock of wheat and wDDGS and showed the potential of using biomolecular vibrational spectroscopy to identify differences among feedstock batches and their co-products.

\section{ACKNOWLEDGMENTS}

This research was supported by grants from the ABIP-FOBI funding, Ministry of Agriculture Strategic Feed Research Chair Program, Beef Cattle Research Council (BCRC, Science Cluster), and the Saskatchewan Agricultural Development Fund (ADF). The authors thank G. Penner for sitting in the graduate student committee and Z. Niu (both of the University of Saskatchewan, Saskatoon, SK, Canada) for kind laboratory assistance. 

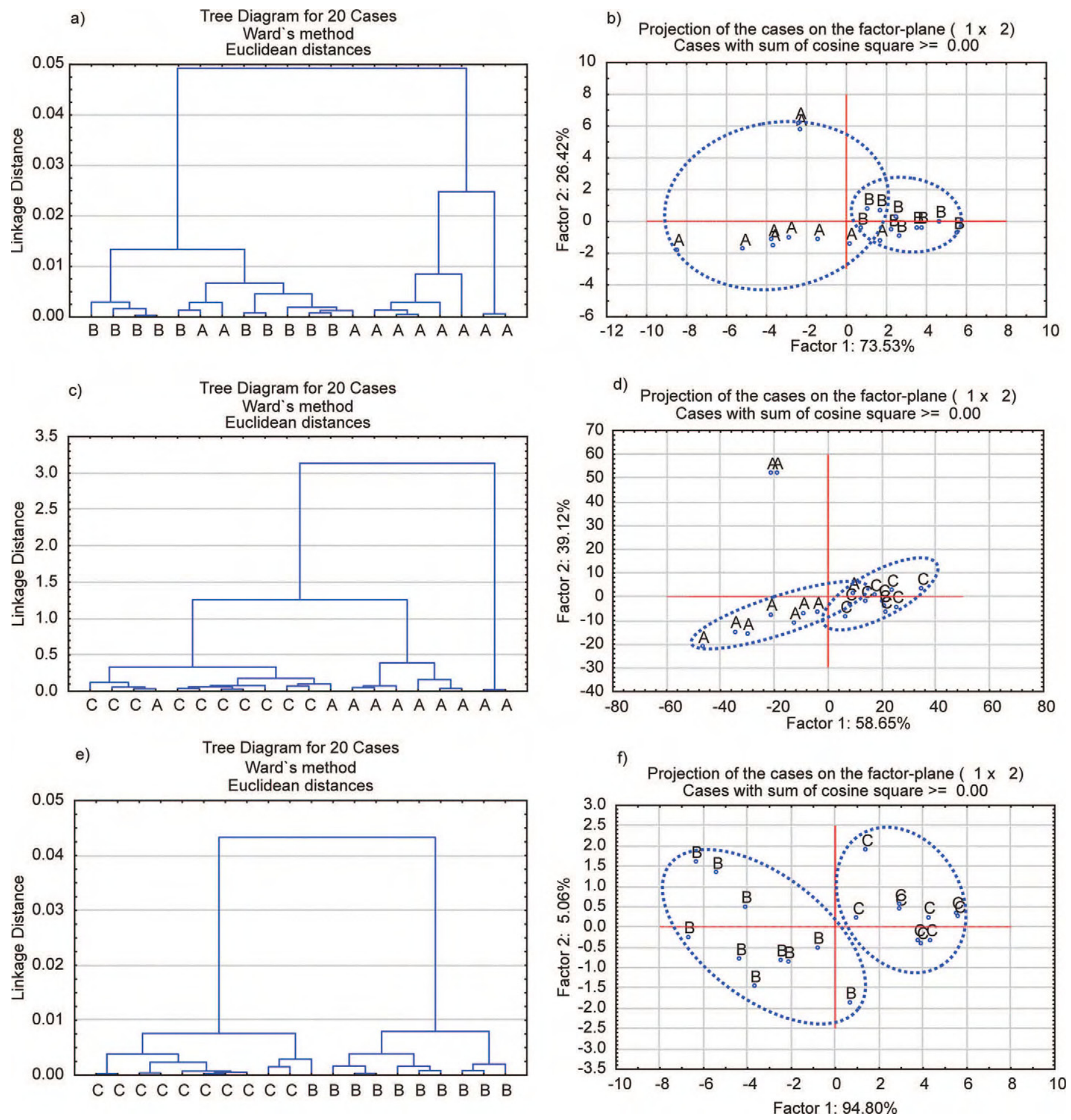

Figure 3. Multivariate molecular spectral analyses in fingerprint region $\left(\sim 1,800-800 \mathrm{~cm}^{-1}\right)$ representing a comparison of 3 batches (batches 1,3 , and 5) of wheat for bioethanol production. Panels a, c, and e show cluster analysis with Euclidean distance and Ward's algorithm cluster methods: panel a compares wheat batch 1 (A) with wheat batch 3 (B), panel c compares wheat batch 1 (A) with wheat batch 5 (C), and panel e compares wheat batch 3 with wheat batch $5(\mathrm{C})$; panels $\mathrm{b}$, d, and f show principal component analysis of the same comparisons shown in panels a, c, and e, respectively. Color version available in the online PDF. 
a)

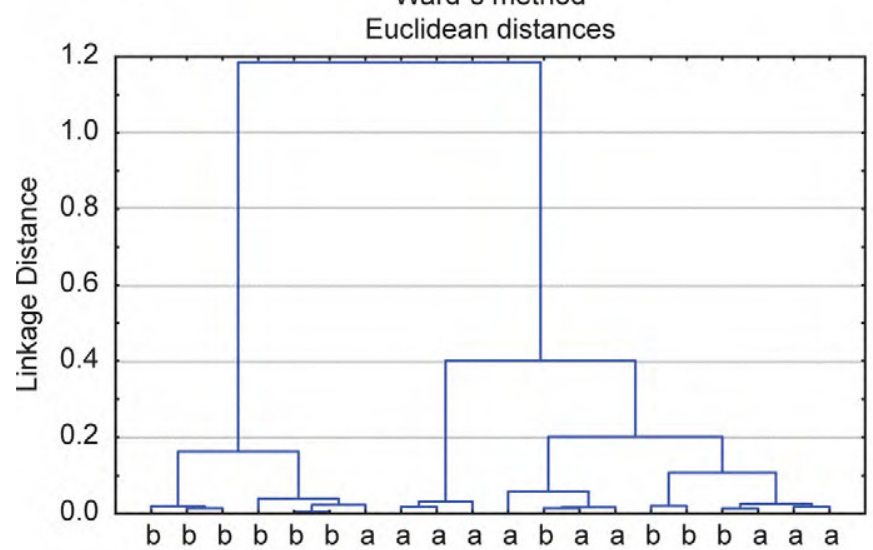

c) Tree Diagram for 20 Cases

Ward's method

Euclidean distances

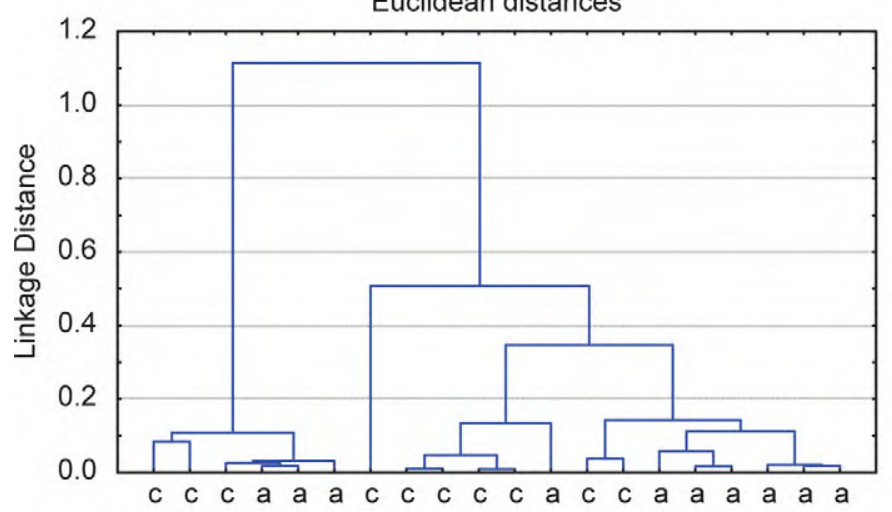

e)

Tree Diagram for 20 Cases

Ward's method

Euclidean distances

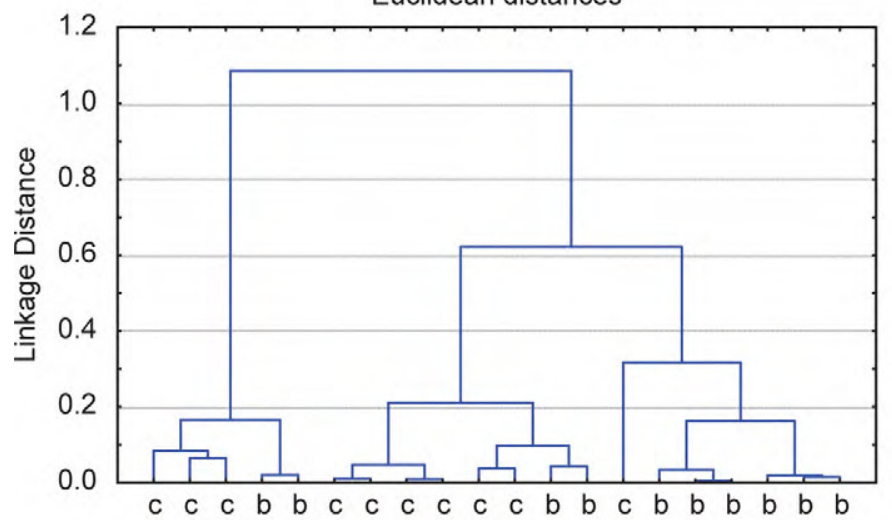

b) Projection of the cases on the factor-plane $\left(\begin{array}{ll}1 \times & 2\end{array}\right)$ Cases with sum of cosine square $>=0.00$

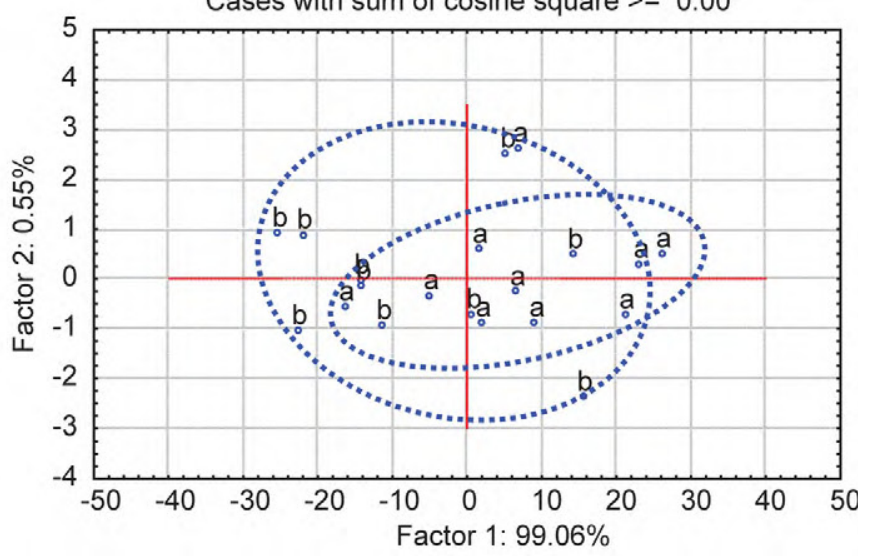

d) Projection of the cases on the factor-plane $\left(\begin{array}{ll}1 \times 2 & 2\end{array}\right)$ Cases with sum of cosine square $>=0.00$

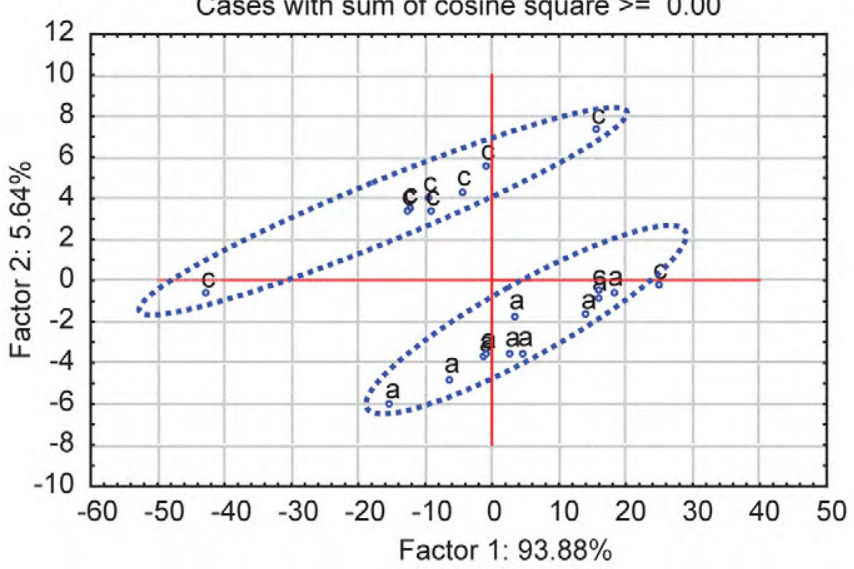

f) Projection of the cases on the factor-plane $\left(\begin{array}{ll}1 \times 2 & 2\end{array}\right)$ Cases with sum of cosine square $>=0.00$

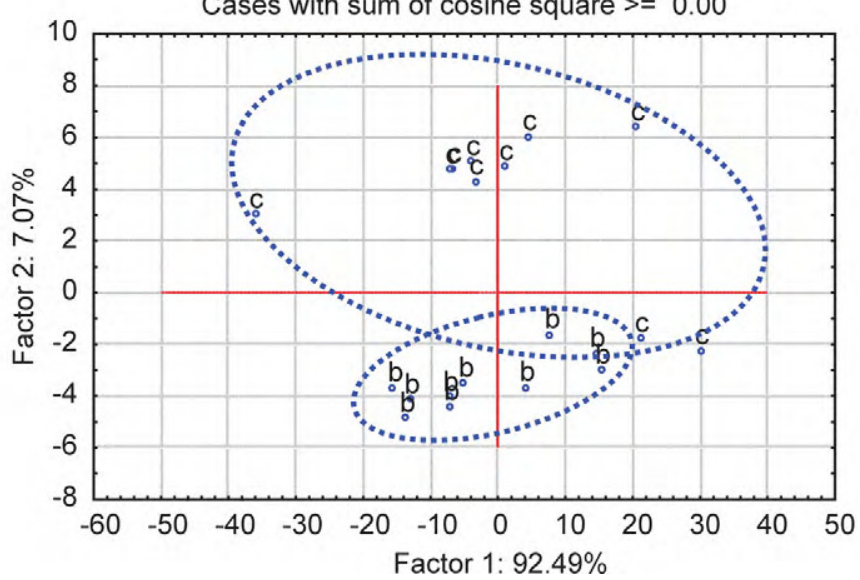

Figure 4. Multivariate molecular spectral analyses in fingerprint region $\left(\sim 1,800-800 \mathrm{~cm}^{-1}\right)$ representing a comparison of 3 batches of coproducts (wheat distillers dried grains with solubles, wDDGS) from bioethanol processing (batches I, III, and V). Panels a, c, and e show cluster analysis with Euclidean distance and Ward's algorithm cluster methods: panel a compares wDDGS batch I (a) with wDDGS batch III (b), panel c compares wDDGS batch I (a) with wDDGS batch V (c), and panel e compares wDDGS batch III (b) with wDDGS batch V (c); panels $\mathrm{b}$, d, and $\mathrm{f}$ show principal component analysis of the same comparisons shown in panels a, c, and e, respectively. Color version available in the online PDF. 


\section{REFERENCES}

AOAC. 1990. Official Methods of Analysis. Association of Official Analytical Chemists. Washington, DC.

Arieli, A., A. Ben-Moshe, S. Zamwel, and H. Tagari. 1989. In situ evaluation of the ruminal and intestinal digestibility of heat-treated whole cottonseeds. J. Dairy Sci. 72:1228-1233.

Azarfar, A., S. Tamminga, and H. Boer. 2007. Effects of washing procedure, particle size and dilution on the distribution between nonwashable, insoluble washable and soluble washable fractions in concentrate ingredients. J. Sci. Food Agric. 87:2390-2398.

Batal, A., and N. Dale. 2003. Mineral composition of distillers dried grains with solubles. J. Appl. Poult. Res. 12:400-403.

Belyea, R. L., K. Rausch, and M. Tumbleson. 2004. Composition of corn and distillers dried grains with solubles from dry grind ethanol processing. Bioresour. Technol. 94:293-298.

Belyea, R. L., T. E. Clevenger, V. Singh, M. Tumbleson, and K. D. Rausch. 2006. Element concentrations of dry-grind corn-processing streams. Appl. Biochem. Biotechnol. 134:113-128.

Belyea, R. L., K. D. Rausch, T. E. Clevenger, V. Singh, D. B. Johnston, and M. E. Tumbleson. 2010. Sources of variation in composition of DDGS. Anim. Feed Sci. Technol. 159:122-130.

Boila, R. J., and J. R. Ingalls. 1994a. The ruminal degradation of dry matter, nitrogen and amino acids in wheat-based distillers dried grains in sacco. Anim. Feed Sci. Technol. 48:57-72.

Boila, R. J., and J. R. Ingalls. 1994b. The post-ruminal digestion of dry matter, nitrogen and amino acids in wheat-based distillers dried grains and canola meal. Anim. Feed Sci. Technol. 49:173-188.

Calsamiglia, S., and M. D. Stern. 1995. A three-step in vitro procedure for estimating intestinal digestion of protein in ruminants. J. Anim. Sci. 73:1459-1465.

CCAC. 1993. Guide to the Care and Use of Experimental Animals. 2nd ed. Canadian Council of Animal Care, Ottawa, ON, Canada.

Chalupa, W., and C. J. Sniffen. 1994. Carbohydrate, protein and amino acid nutrition of lactating dairy cattle. Pages 31-40 in Recent Advanced Animal Nutrition. Nottingham University Press, Nottingham, UK.

CRFA (Canadian Renewable Fuel Association). 2010. Advanced biofuels in Canada-The future is now. Accessed May 2011. http:// www.greenfuels.org/en/media-centre/release-archive.aspx.

Cromwell, G. L., K. Herkelman, and T. Stahly. 1993. Physical, chemical, and nutritional characteristics of distillers dried grains with solubles for chicks and pigs. J. Anim. Sci. 71:679-686.

Cytospec. 2004. Software for Infrared Spectral Imaging, v. 1.1.01. Accessed Jul. 23, 2012. http://www.cytospec.com/.

Czerkawski, J. W. 1986. An Introduction to Rumen Studies. Pergamon Press, Oxford, UK.

Dhanoa, M. S. 1988. On the analysis of Dacron bag data for low degradability feeds (research note). Grass Forage Sci. 43:441-444.

Doiron, K. J., P. Yu, C. R. Christensen, D. A. Christensen, and J. J. McKinnon. 2009a. Detecting molecular changes in Vimy flaxseed protein structure using synchrotron FTIRM and DRIFT spectroscopic techniques: Structural and biochemical characterization. Spectroscopy 23:307-322.

Doiron, K. J., P. Yu, J. J. McKinnon, and D. A. Christensen. 2009b. Heat-induced protein structures and protein subfractions in relation to protein degradation kinetics and intestinal availability in dairy cattle. J. Dairy Sci. 92:3319-3330.

Gibb, D. J., X. Hao, and T. A. McAllister. 2008. Effect of dried distillers' grains from wheat on diet digestibility and performance of feedlot cattle. Can. J. Anim. Sci. 88:659-665.

Goelema, J. O. 1999. Processing of legume seeds: Effects on digestive behaviour in dairy cows. PhD Thesis. Wageningen University, Wageningen, the Netherlands.

Hall, M. B., B. A. Lewis, P. J. Van Soest, and L. E. Chase. 1997. A simple method for estimation of neutral detergent-soluble fiber. J. Sci. Food Agric. 74:441-449.

Jackson, M., and H. Mantsch. 2002. Vibrational Spectroscopy and Pathology: Handbook of Vibrational Spectroscopy. John Wiley \& Sons, New York, NY.
Jackson, M., and H. H. Mantsch. 1995. The use and misuse of FTIR spectroscopy in the determination of protein structure. Crit. Rev. Biochem. Mol. Biol. 30:95-120.

Jackson, M., and H. H. Mantsch. 2000. Ex vivo tissue analysis by infrared spectroscopy. Pages 131-156 in Encyclopedia of Analytical Chemistry. Vol. 1. R. A. Meyers, ed. John Wiley \& Sons, Chichester, UK.

Jonker, A., M. Y. Gruber, Y. Wang, B. Coulman, J. J. McKinnon, D. A. Christensen, and P. Yu. 2012. Foam stability of leaves from anthocyanidin-accumulating Lc-alfalfa and relation to molecular structures detected by FTIR vibration spectroscopy. Grass Forage Sci. 67:369-381.

Kleinschmit, D. H., J. L. Anderson, D. J. Schingoethe, K. F. Kalscheur, and A. R. Hippen. 2007. Ruminal and intestinal degradability of distillers grains plus solubles varies by source. J. Dairy Sci. 90:2909-2918.

Krishnamoorthy, U., T. V. Muscato, C. J. Sniffen, and P. J. Van Soest. 1982. Nitrogen fractions in selected feedstuffs. J. Dairy Sci. $65: 217-225$

Licitra, G. T. M. Hernandez, and P. J. Van Soest. 1996. Standardization of procedures for nitrogen fractionation of ruminant feeds. Anim. Feed Sci. Technol. 57:347-358.

Liu, K. S., and J. C. Han. 2011. Changes in mineral concentrations and phosphorus profile during dry-grind processing of corn into ethanol. Bioresour. Technol. 102:3110-3118.

Marinkovic, N. S., and M. R. Chance. 2005. Synchrotron infrared microspectroscopy. Page 671-708 in Encyclopedia of Molecular Cell Biology and Molecular Medicine. R. Meyers, ed. Wiley, New York, NY.

McAllister, M. M., D. H. Gould, M. F. Raisbeck, B. A. Cummings, and G. H. Loneragan. 1997. Evaluation of ruminal sulfide concentrations and seasonal outbreaks of polioencephalomalacia in beef cattle in a feedlot. J. Am. Vet. Med. Assoc. 211:1275-1279.

McCleary, B. V., C. C. Gibson, and C. C. Mugford. 1997. Measurements of total starch in cereal products by amyloglucosidase alpha-amylase method. J. AOAC Int. 80:571-579.

NRC. 1996. Nutrient Requirements of Beef Cattle. 7th ed. National Academy Press. Washington, DC.

NRC. 2001. Nutrient Requirements of Dairy Cattle. 7th ed. National Academy Press, Washington, DC.

Netemeyer, D. T., L. J. Bush, J. W. Ward, and S. A. Jafri. 1982. Effect of heating soybean meal for dairy cows. J. Dairy Sci. 65:235-241.

Nia, S. A. M., and J. R. Ingalls. 1992. Effect of heating on canola meal protein degradation in the rumen and digestion in the lower gastrointestinal tract of steers. Can. J. Anim. Sci. 72:83-88.

Nuez-Ortín, W. G., and P. Yu. 2009. Nutrient variation and availability of wheat DDGS, corn DDGS and blend DDGS from bioethanol plants. J. Sci. Food Agric. 89:1754-1761.

Nuez-Ortín, W. G., and P. Yu. 2010. Estimation of ruminal and intestinal digestion profiles, hourly degradation ratio and potential $\mathrm{N}$ to energy synchronization of co-products of bioethanol production. J. Sci. Food Agric. 90:2058-2067.

Ørskov, E. R., F. D. B. Hovell, and F. Mould. 1980. The use of the nylon bag technique for the evaluation of feedstuffs. Trop. Anim. Prod. 5:195-213.

Ørskov, E. R., and I. McDonald. 1979. The estimation of protein degradability in the rumen from incubation measurements weighted according to rate of passage. J. Agric. Sci. 92:499-503.

Pfost, H., and V. Headley. 1976. Methods of determining and expressing particle size. Pages 512-520 in Feed Manufacturing Technology II; Appendix C. H. Pfost, ed. Am. Feed Manuf. Assoc., Arlington, VA

Rausch, K. D., and R. L. Belyea. 2006. The future of coproducts from corn processing. Appl. Biochem. Biotechnol. 128:47-86.

Robinson, P. H., J. G. Fadel, and S. Tamminga. 1986. Evaluation of mathematical models to describe neutral detergent residue in terms of its susceptibility to degradation in the rumen. Anim. Feed Sci. Technol. 15:249-271.

Roe, M. B., C. J. Sniffen, and L. E. Chase. 1990. Techniques for measuring protein fractions in feedstuffs. Pages 81-88 in Proc. Cornell Nutr. Conf. Dept. Anim. Sci. Cornell University, Ithaca, NY. 
Sahlu, T., D. J. Schingoethe, and A. K. Clark. 1984. Lactational and chemical evaluation of soybean meals heat-treated by two methods. J. Dairy Sci. 67:1725-1738.

SAS Institute. 2009. User's Guide: Statistics. Version 9.2. SAS Institute Inc., Cary, NC.

Saxton, A. M. 1998. A macro for converting mean separation output to letter groupings in PROC MIXED. Pages 1243-1246 in 23rd SAS User Group Intl. SAS Institute, Cary, NC

Shurson, J., M. Spiehs, M. Whitney, S. Baidoo, L. Johnston, B. Shanks, and D. Wulf. 2001. The value of distillers dried grains with solubles in swine diets. Pages 22-52 in Minnesota Nutr. Conf./ Minnesota Corn Growers Assoc. Tech. Symp., Bloomington, MN.

Sinclair, L. A., P. C. Garnsworthy, J. R. Nwebold, and P. J. Buttery. 1993. Effect of synchronizing the rate of dietary energy and nitrogen release on rumen fermentation and microbial protein synthesis in sheep. J. Agric. Sci. 124:463-472.

Sniffen, C. J., J. D. O'connor, P. J. Van Soest, D. G. Fox, and J. B. Russell. 1992. A net carbohydrate and protein system for evaluating cattle diets: II. Carbohydrate and protein availability. J. Anim. Sci. 70:3562-3577.

Sockalingum, G. D., W. Bouhedja, P. Pina, P. Allouch, C. Bloy, and M. Manfait. 1998. FT-IT spectroscopy as an emerging method for rapid characterization of microorganisms. Cell. Mol. Biol. $44: 261-269$

Spiehs, M. J., and V. H. Varel. 2009. Nutrient excretion and odorant production in manure from cattle fed corn wet distillers grains with solubles. J. Anim. Sci. 87:2977-2984.

Stein, H. H., C. Pedersen, M. L. Gibson, and M. G. Boersma. 2006. Amino acid and energy digestibility in ten samples of distillers dried grain with solubles by growing pigs. J. Anim. Sci. 84:853860 .

Stuart, B. 2004. Infrared Spectroscopy: Fundamentals and Applications. John Wiley, Chichester, UK.

Tamminga, S., G. G. Brandsma, J. Dijksta, G. V. Duinkerken, A. M. V. Vuuren, and M. C. Blok. 2007. Protein evaluation for ruminants: The DVE/OEB 2007 system. CVB documentation report no. 53. CVB, Lelystad, the Netherlands.

Tamminga, S., W. M. Van Straalen, A. P. J. Subnel, R. G. M. Meijer, A. Steg, C. J. G. Wever, and M. C. Blok. 1994. The Dutch protein evaluation system: The DVE/OEB system. Livest. Prod. Sci. 40:139-155.

Tamminga, S., A. M. Vuuren, C. J. Koelen, R. S. Ketelaar, and P. L. Togt. 1990. Ruminal behaviour of structural carbohydrates, nonstructural carbohydrates and crude protein from concentrate ingredients in dairy cows. Neth. J. Agric. Sci. 38:513-526.
Thacker, P. A., and G. P. Widyaratne. 2007. Nutritional value of diets containing graded levels of wheat distillers grains with solubles fed to broiler chicks. J. Sci. Food Agric. 87:1386-1390.

Van Soest, P. J., J. B. Robertson, and B. A. Lewis. 1991. Methods for dietary fiber, neutral detergent fiber, and nonstarch polysaccharides in relation to animal nutrition. J. Dairy Sci. 74:3583-3597.

Weiss, W. P., H. R. Conrad, and W. L. Shockey. 1986. Amino acid profiles of heat-damaged Grasses1. J. Dairy Sci. 69:1824-1836.

Weiss, W. P., H. R. Conrad, and N. R. St Pierre. 1992. A theoretically based model for predicting total digestible nutrient values of forages and concentrates. Anim. Feed Sci. Technol. 39:95-110.

Wetzel, D. L., A. J. Eilert, L. N. Pietrzak, S. S. Miller, and J. A. Sweat. 1998. Ultraspatially-resolved synchrotron infrared microspectroscopy of plant tissue in situ. Cell. Mol. Biol. (Noisy-legrand) 44:145-168.

Widyaratne, G. P., and R. T. Zijlstra. 2007. Nutritional value of wheat and corn distillers dried grains with solubles: Digestibility and digestible contents of energy, amino acids and phosphorus, nutrient excretion and growth performance of grower-finisher pigs. Can. J. Anim. Sci. 87:103-114.

Yu, P. 2004. Application of advanced synchrotron radiation-based Fourier transform infrared (SR-FTIR) microspectroscopy to animal nutrition and feed science: A novel approach. Br. J. Nutr. 92:869-885.

Yu, P. 2005. Applications of hierarchical cluster analysis (CLA) and principal component analysis (PCA) in feed structure and feed molecular chemistry research, using synchrotron-based Fourier transform infrared (FTIR) microspectroscopy. J. Agric. Food Chem. 53:7115-7127.

Yu, P. 2006. Synchrotron IR microspectroscopy for protein structure analysis: Potential and questions. Spectroscopy 20:229-251.

Yu, P. 2010. Plant-based food and feed protein structure changes induced by gene-transformation, heating and bio-ethanol processing: A novel synchrotron-based molecular structure and nutrition research program. Mol. Nutr. Food Res. 54:1535-1545.

Yu, P. D. Damiran, A. Azarfar, and Z. Niu. 2011. Detecting molecular features of spectra mainly associated with structural and non-structural carbohydrates in co-products from bioethanol production using DRIFT with uni and multivariate molecular spectral analyses. Int. J. Mol. Sci. 12:1921-1935.

Yu, P., J. O. Goelema, and S. Tamminga. 2000. Using the DVE/ OEB model to determine optimal conditions of pressure toasting on horse beans (Vicia faba) for the dairy feed industry. Anim. Feed Sci. Technol. 86:165-176. 